\title{
Applying a Meta-Synthesis Qualitative Approach to Identify and Investigate Factors Affecting Financial Reporting Bias
}

\author{
FaezehPasandidehfard \\ ccountingMA student, Tarbiat Modarres University, Tehran, Iran \\ pasandidehfardfaezeh@yahoo.com \\ kazem Vadizadeh \\ Department of Accounting, Science and Research Branch, Islamic Azad \\ University, Tehran, Iran \\ karshenas_rasmi@gmail.com \\ Sahar Sepasi* \\ AccountingAssociate Professor,Tarbiat Modarres University, \\ Tehran(Corresponding Author) \\ sepasi@modares.ac.ir
}

\begin{abstract}
:
One of the effective factors in reducing the reliability of reports and financial statements is the phenomenon of fraud and error which increases the risk and cost of business, decreases investor's confidence and questions the integrity of accounting and auditing profession. The purpose of this study is to identify and investigate the factors affecting financial reporting bias. To this end, a qualitative research approach and meta-synthesis tools including seven steps have been carried out to systematically evaluate and analyze the findings of previous research. At the end, the data of 18 experts and professors were collected by a questionnaire in 2019 and using Shannon entropy quantitative method to determine the impact factor of identified factors based on content analysis approach. Finally, the factors that have the most impact on financial reporting bias are identified. The results of this study are helpful to professional auditors and corporate financial managers in identifying the factors that influence fraud and error.
\end{abstract}

Keyword: Financial reporting bias, fraud, error, Meta-Synthesis

Copyrights

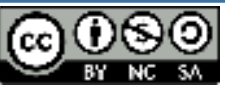

This license only allowing others to download your works and share them with others as long as they credit you, but they can't change them in any way or use them commercial. 
مقاله يُؤوهشى

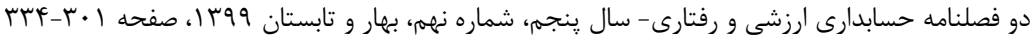

شناسايى عوامل مؤثر بر تزارشكرى مالى متقلبانه و نادر ست با استفاده از روش فراتركيب

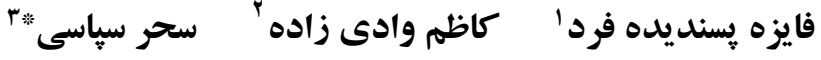

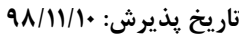

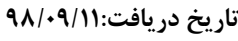

جكيده

از عوامل مؤثر در كاهش اعتماد يذيرى كزارشها و صورتهاى مالى يديده تقلب و اشتباه

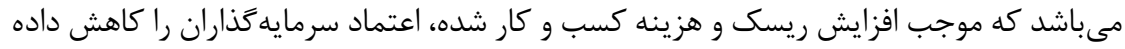

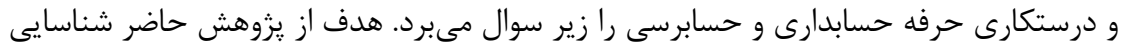

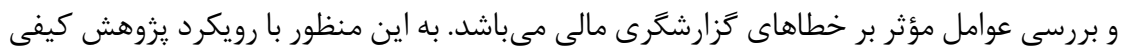

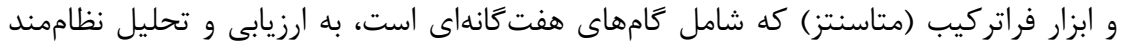

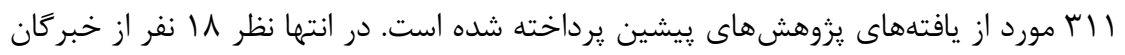

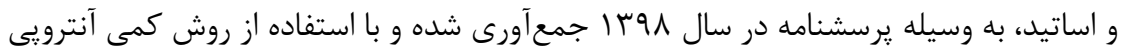
شانون، براساس رويكرد تحليل محتوا به تعيين ضريب اثر عوامل شناسايى شده، يرداخته شد. در

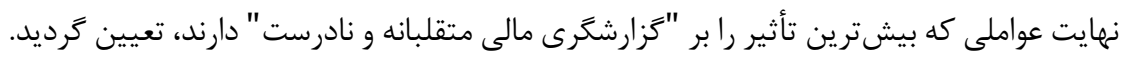

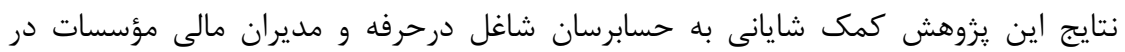
شناسايى عوامل مؤثر در وقوع تقلب و اشتباه، مى كند.

وازًَان كليدى: كَارشكَى متقلبانه و نادرست، تقلب، اشتباه، متاسنتز.

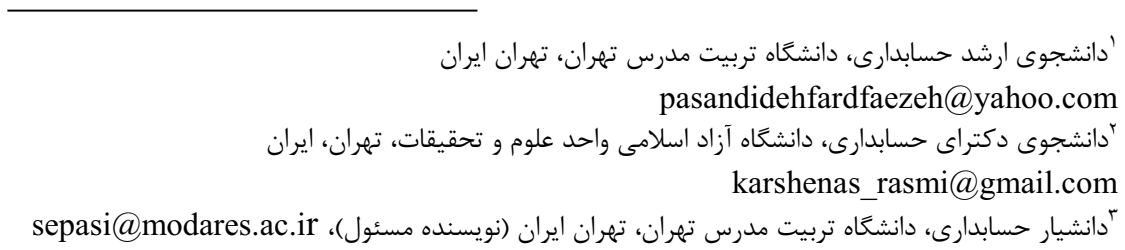


واحدهاى تجارى در سرتاسر جهان براى رشد و توسعه، نيازمند تأمين مالى هستند. با اين

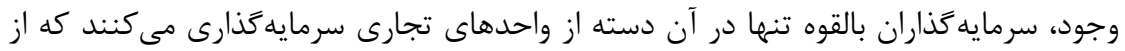

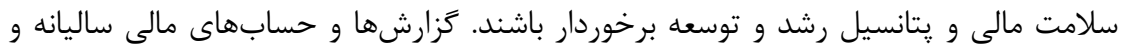

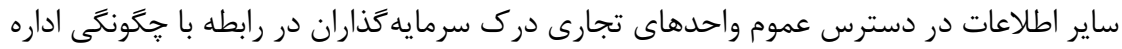

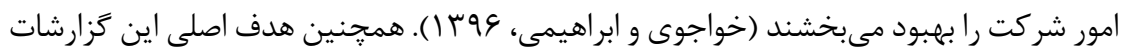
مالى نيز بيان آثار اقتصادى رويدادها و عمليات مالى بر وضعيت و عملكرد واحد تجارى بردي براى إنى

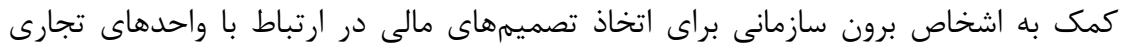

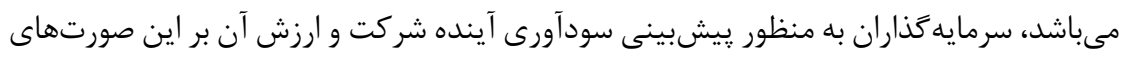

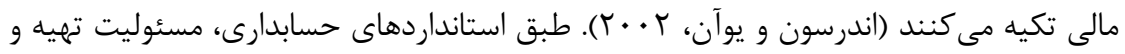

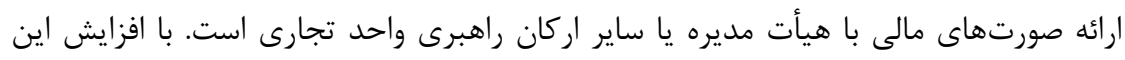

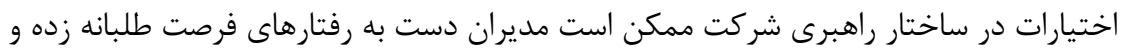

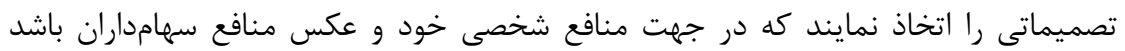
(حجازى و مختارى نزاد، وهب ا).

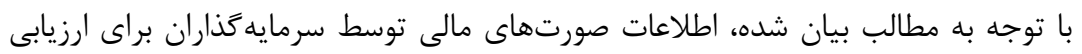

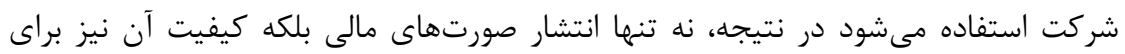

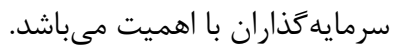

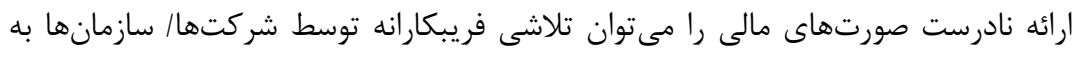

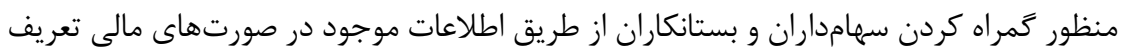

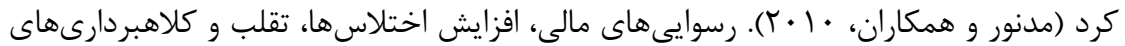

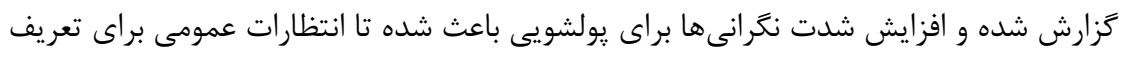

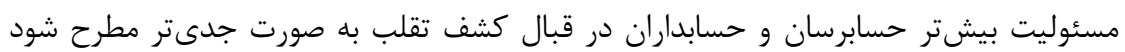

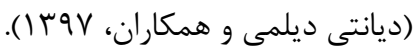

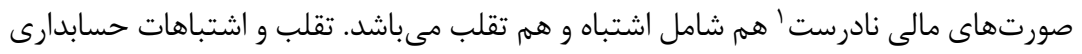

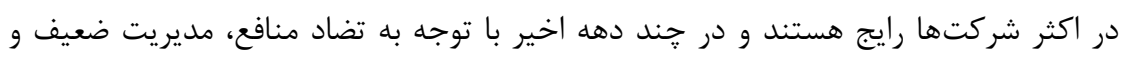

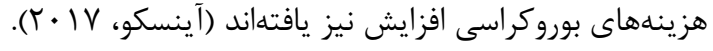

${ }^{1}$ False Financial Statement (FFS) 
$r+r$ دكتر سباسى و همكاران، شناسايى عوامل مؤثر بر تَزارشكَى مالى متقلبانه و نادرست با استفاده ...

تعريفهاى زيادى از تقلب' و اشتباه د در مفهوم كلى خود از طرف حرفه و مجامع بينالمللى

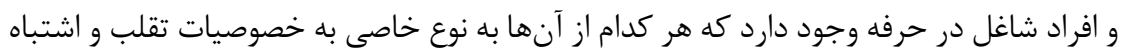

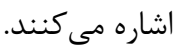

امروزه از تقلب به عنوان جدى ترين تهديد براى منافع عمومى و بازار سرمايه ياد مىشود؛

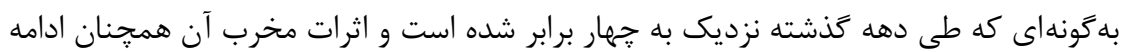

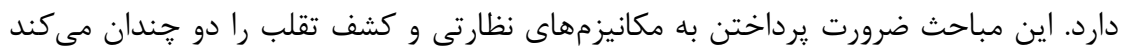

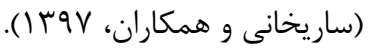

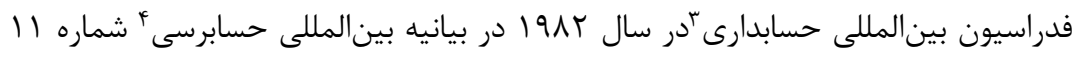

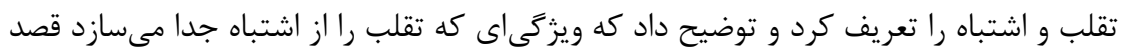

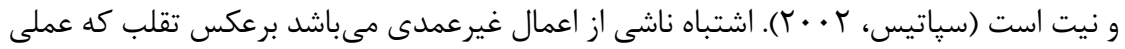

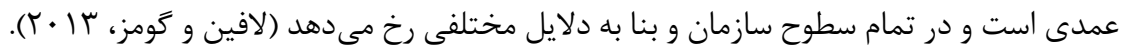

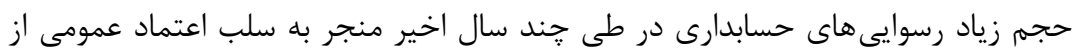
شركتهاى بزرى و مؤسسات حسابرسى آنها شده است. تمام اين رسوايىها، همراه با تجديد

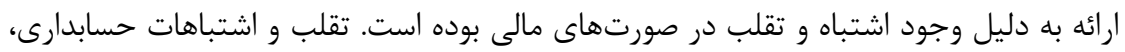
نه تنها به صاحبان شركتها و سرمايه كذاران، بلكه به كاركنان، موسسات اعتبارى و شركتهاي

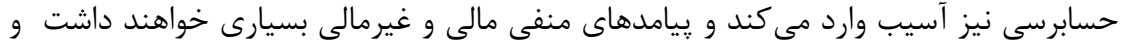
درنهايت در سطح كلان باعث ايجاد بحران اقتصادى در جامعه مىشود، به همين دليل موضوع

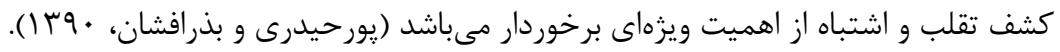

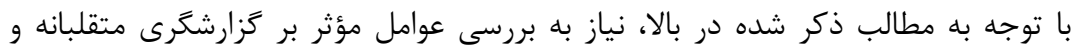

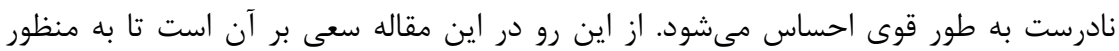

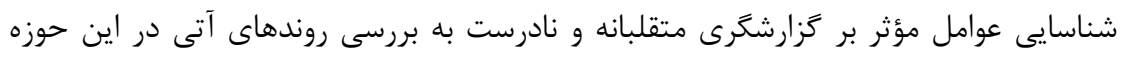

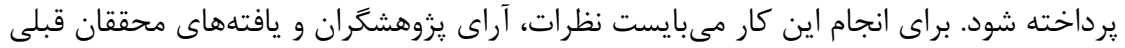

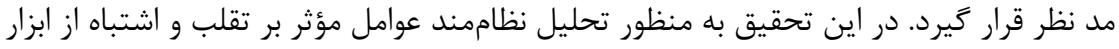
متاسنتز (فراتركيب) استفاده شده است. در ادامه نخست به بررسى و مطالعه تحقيقات مرتبط با خطاهاى كزارشكرى مالى ثرداخته و

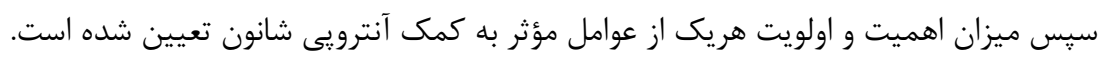

1 fraud

${ }^{2}$ Error

${ }^{3}$ The International Federation Accountants

${ }^{4}$ ISA 


\section{r-مبانى نظرى و وِيشينه يزوهش}

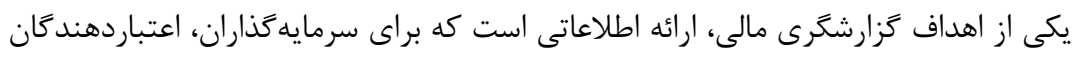

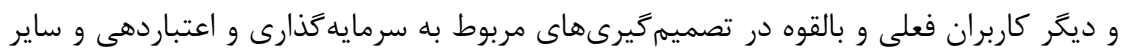

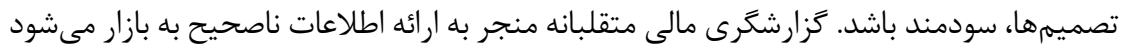

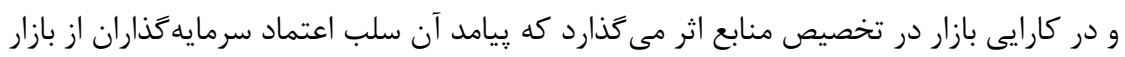

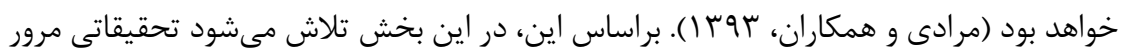

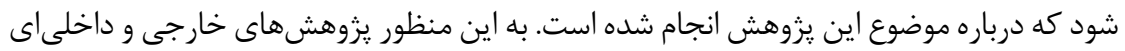

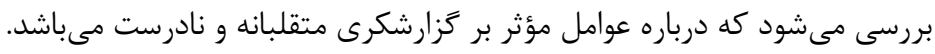

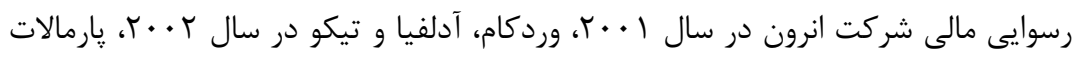

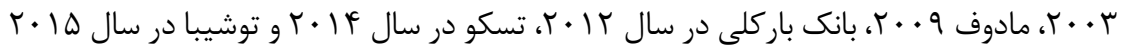

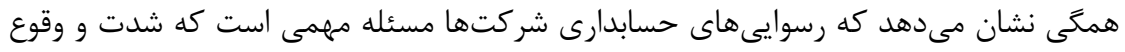
آن در جهان رو به افزايش است دهان

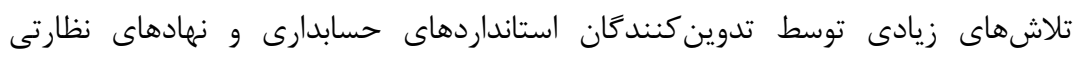

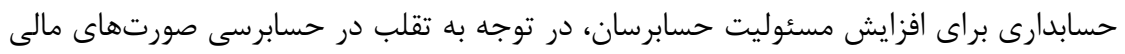

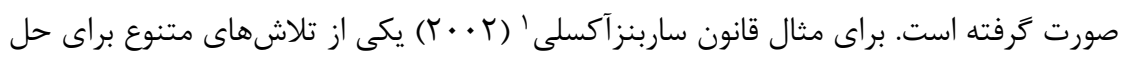

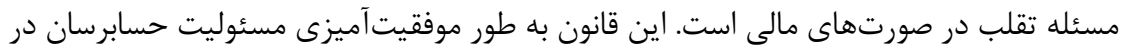

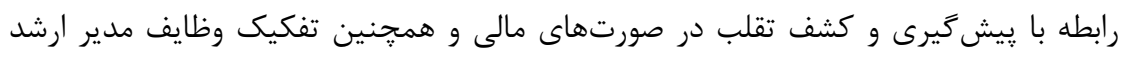

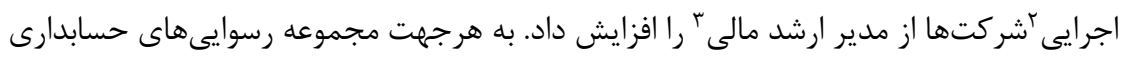

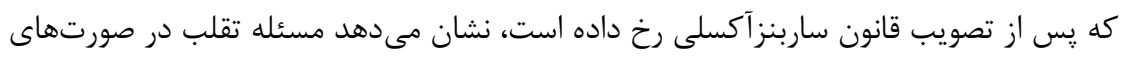

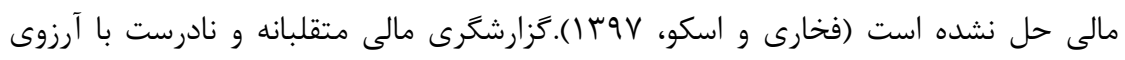

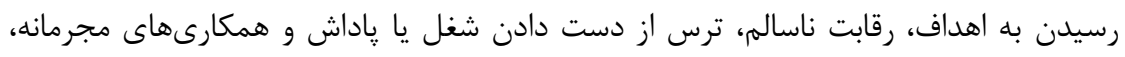

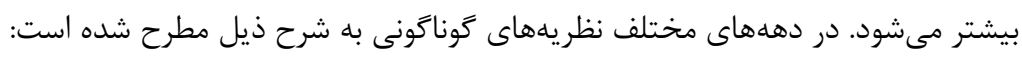

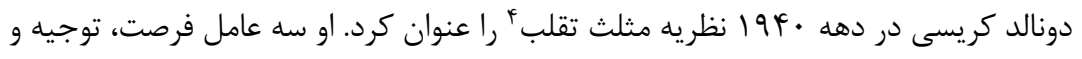

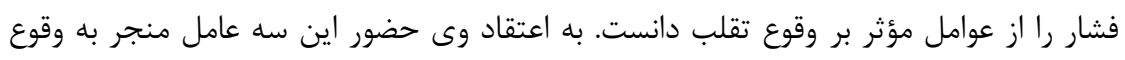

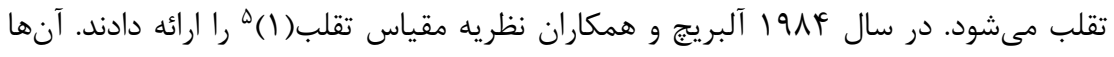

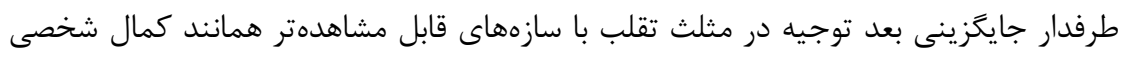

${ }^{1}$ Sarbanes Oxley

${ }^{2} \mathrm{CEO}$

${ }^{3} \mathrm{CFO}$

${ }^{4}$ Fraud Triangle

${ }^{5}$ Fraud Scale 1 
بودند. نويسندكانى مانند ولف و هرمانسون (Y (F) معتقدند كه مثلث تقلب مىتواند با

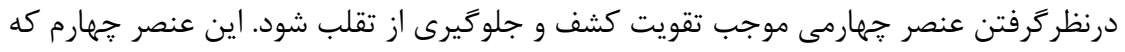

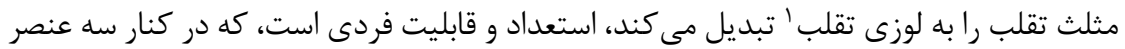

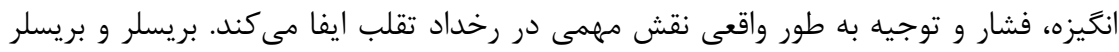

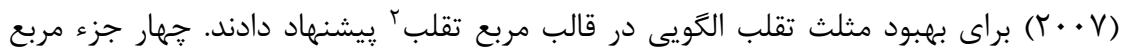

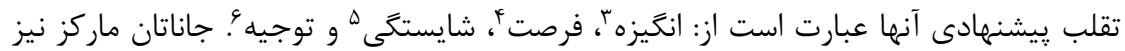

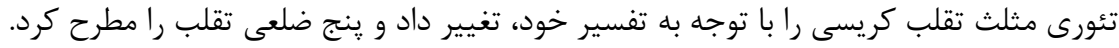

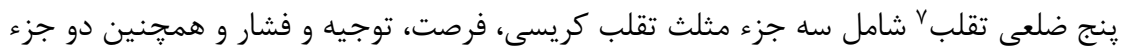

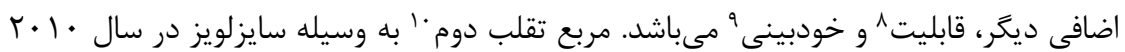

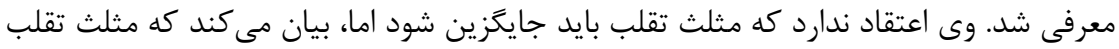

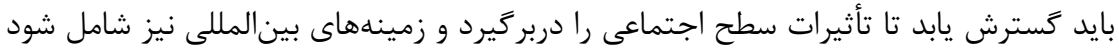

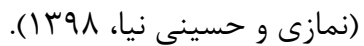
در سال • • ·توسط كلدمن لوزى تقلب كه در صنايع خدمات مالى به كار مىرفت، با اضافه

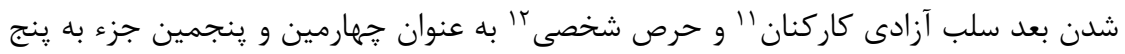

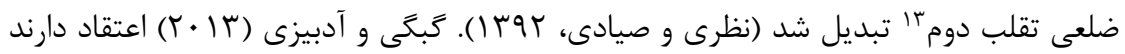

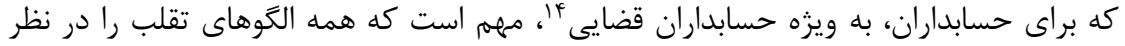

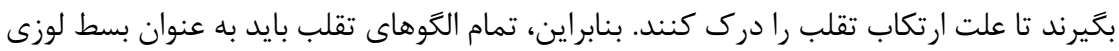

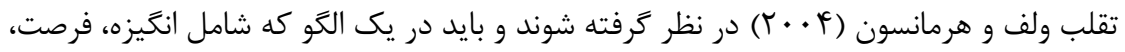

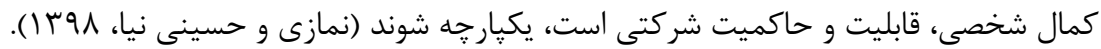

${ }^{1}$ Fraud Diamond

${ }^{2}$ Fraud Square

${ }^{3}$ Motivation

${ }^{4}$ Opportunity

${ }^{5}$ Competency

${ }^{6}$ Rationalization

${ }^{7}$ Fraud Pentagon

${ }^{8}$ Capability

${ }^{9}$ Arrogance

${ }^{10}$ Fraud Square 2

${ }^{11}$ Denial of Staff Freedom

${ }^{12}$ Personal Greed

${ }^{13}$ Fraud Pentagon 2

${ }^{14}$ Forensic Accountants 
در نظريه كوه قله يخى'، تقلب مانند كوه يخى است كه روى آب قرار گرفته،، وجوه ساختارى

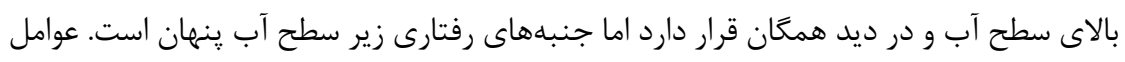

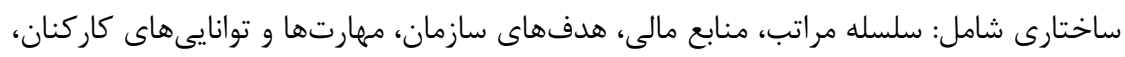

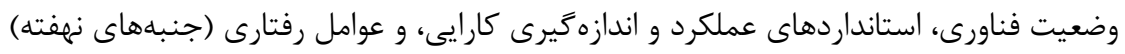

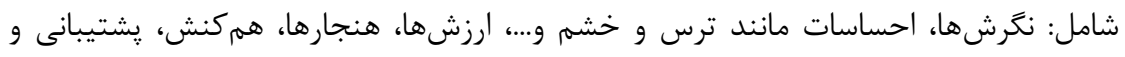

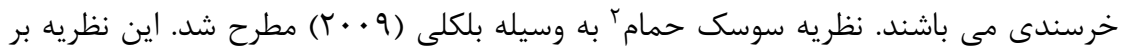

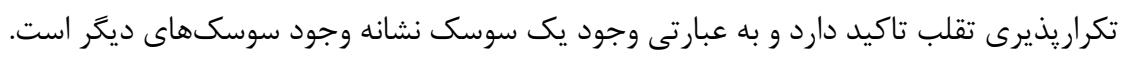

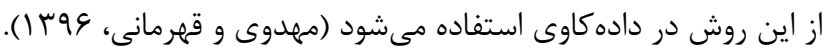

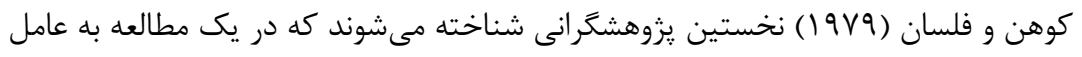

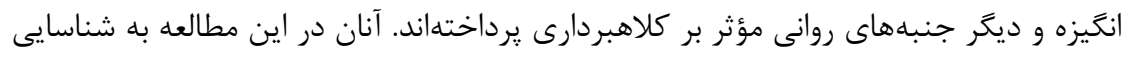

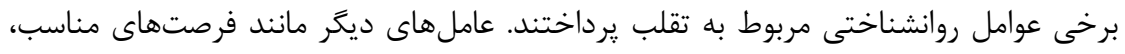

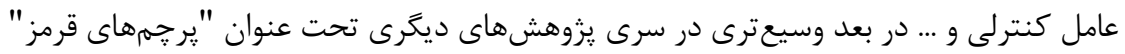

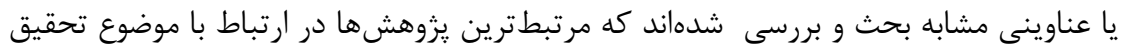

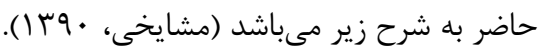

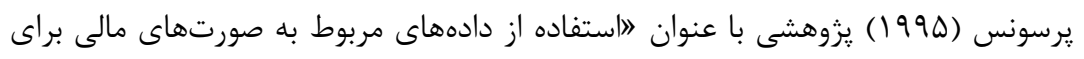

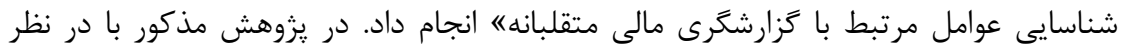

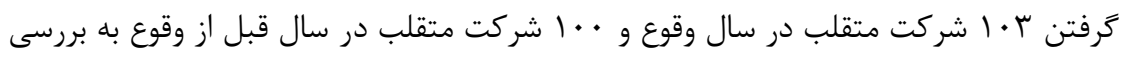

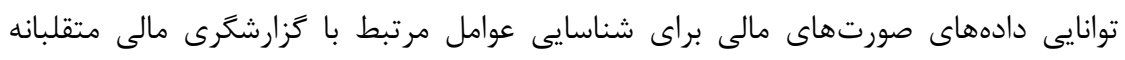

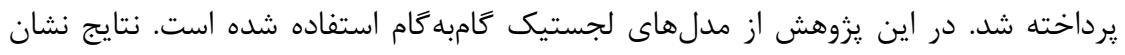

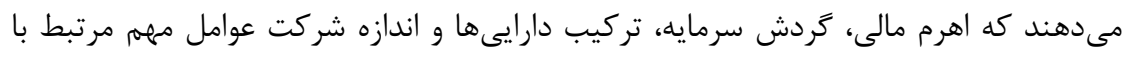

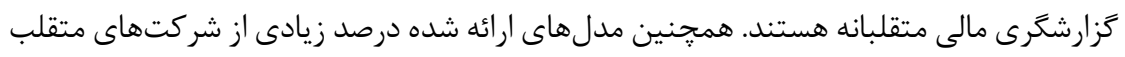
را به طور صحيحى شناسايى كردند.

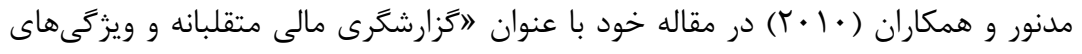

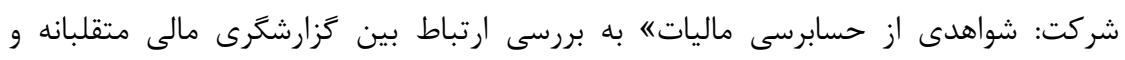

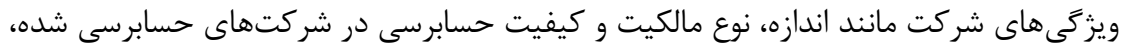

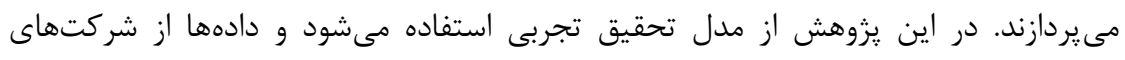

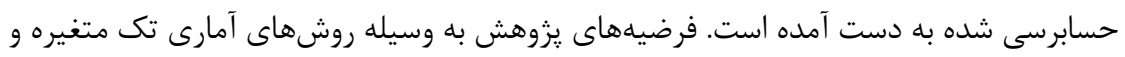

${ }^{1}$ Ice Mountain Peak Theory

${ }^{2}$ Bath Cockroach Theory 
جند متغيره آزمون شدهاند. نتايج حاكى از اين است كه اندازه شركت و كيفيت حسابرسى رابطه معاد

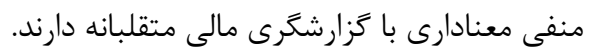

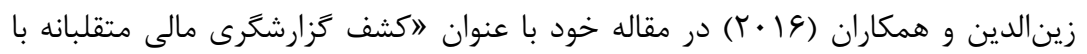

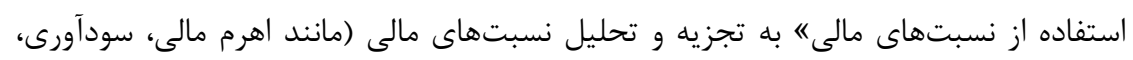

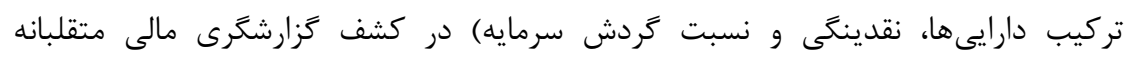

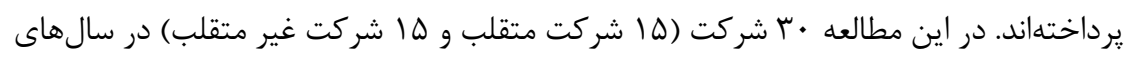

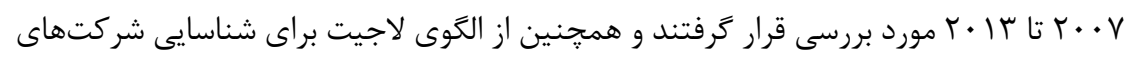

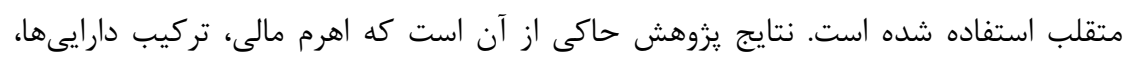

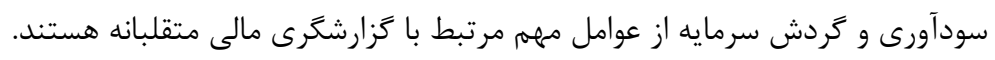

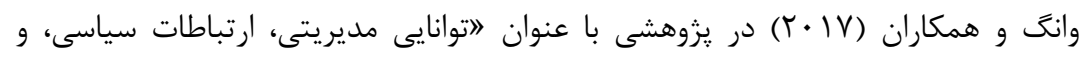

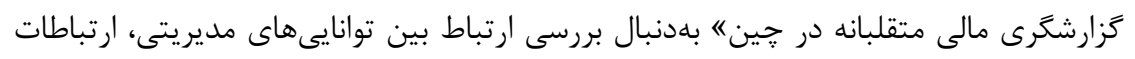

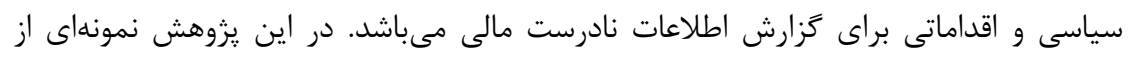

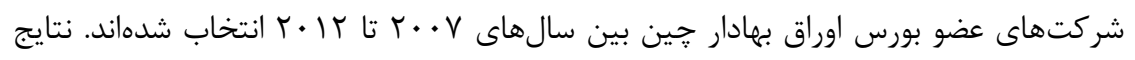

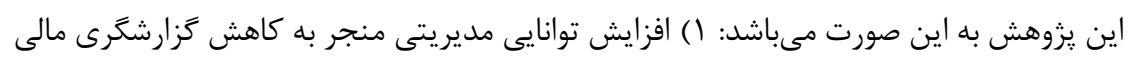

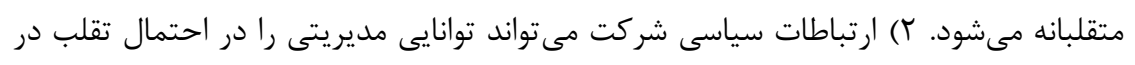

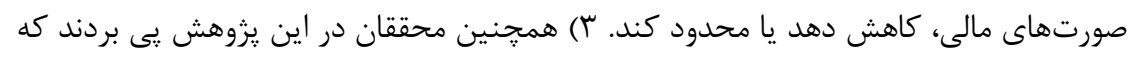

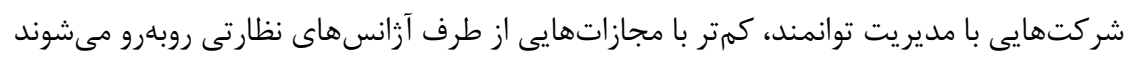
نسبت به شركتهاى فاقد مديريت توانمند.

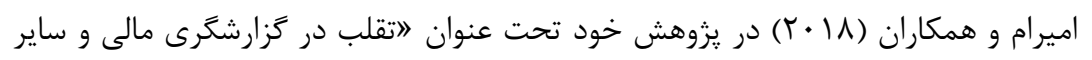

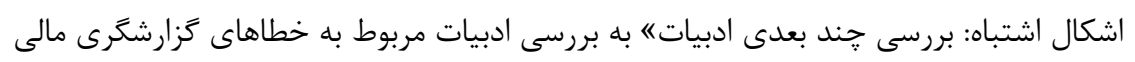

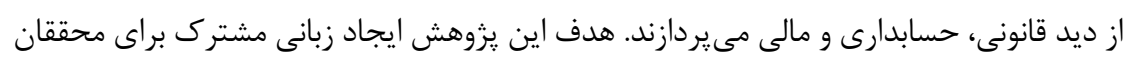

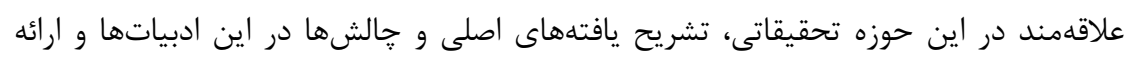

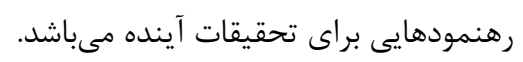

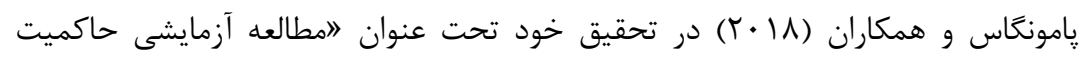

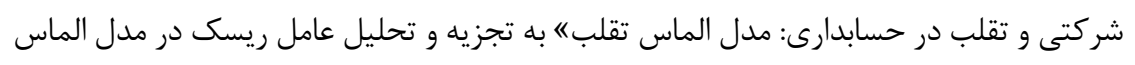

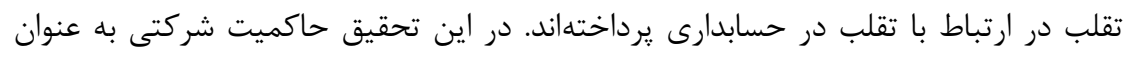

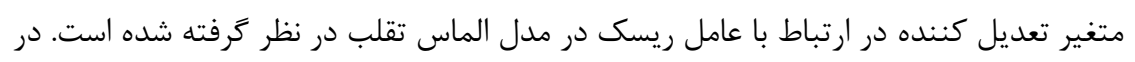

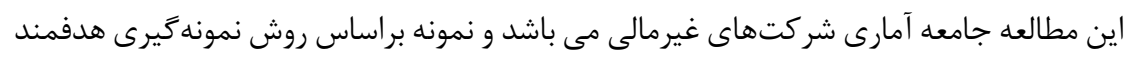

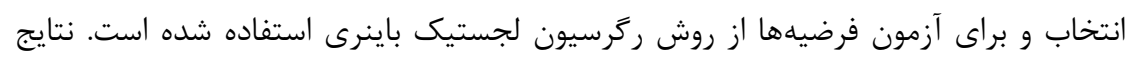


يزوهش نشان مىدهد كه تنها تغيير در مسير' به طور قابل توجهى بر تقلب در حسابدارى تاثير

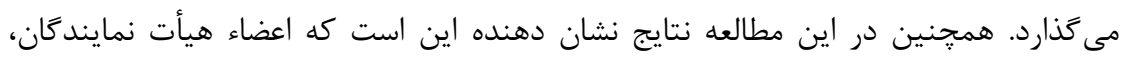

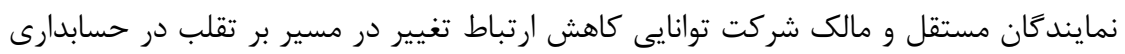

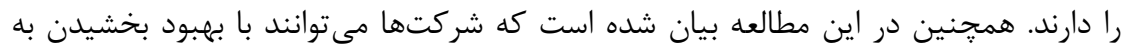

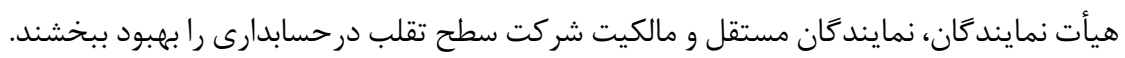

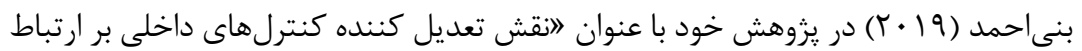

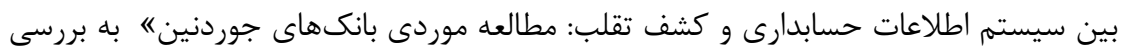

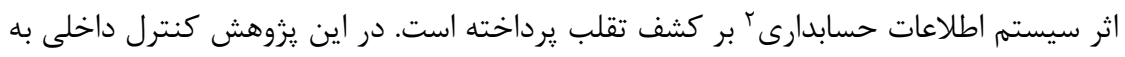

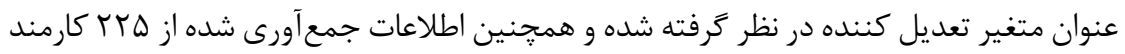

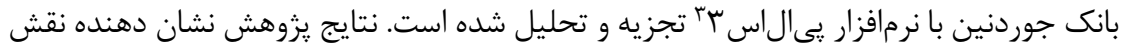

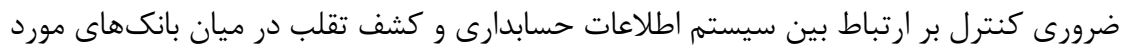

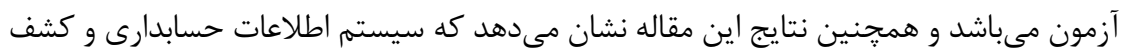
تقلب به طور قابل توجهى به يكديكر همبسته هستند.

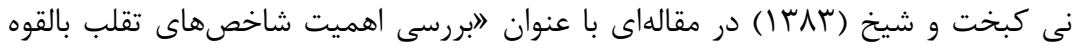

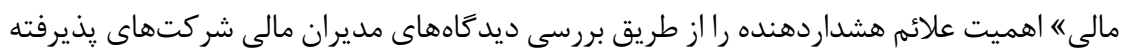
شده در بورس اوراق بهادار تهران و اعضاى جامعه حسابداران رسمى ايران از طريق تران تكنيك تحليل

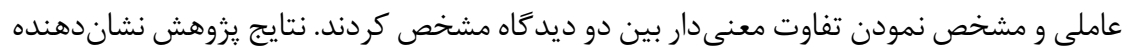

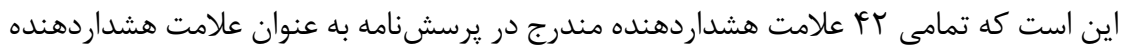

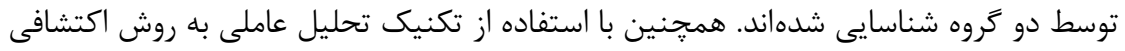

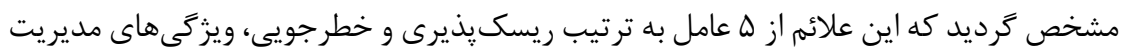

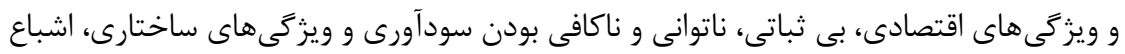

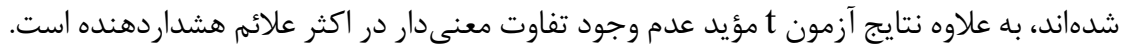

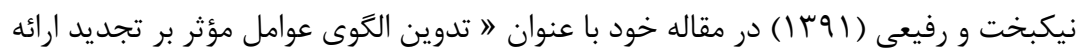

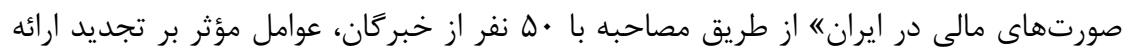

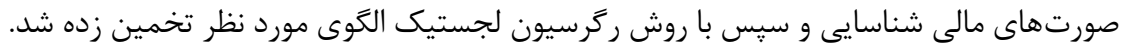

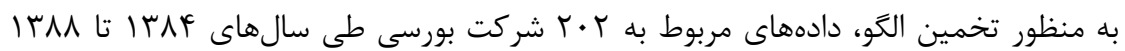

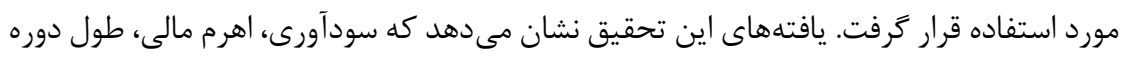

${ }^{1}$ Change in direction

${ }^{2}$ AIS

${ }^{3}$ PLS 3 
تصدى مديريت، تغيير مديريت، تغيير حسابرس و اندازه موسسه حسابرسى بر وقوع تجديد ارائه

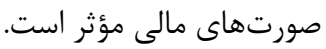

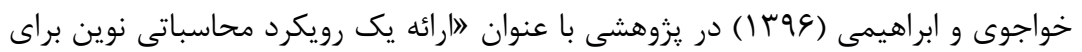
يِيشبينى تقلب در صورتهاى مالى، با استفاده از شيوههاى خوشهبندى و طبقابندى (شواهدى برى

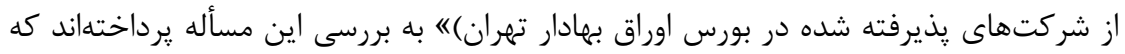

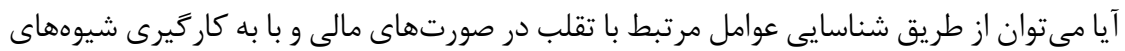

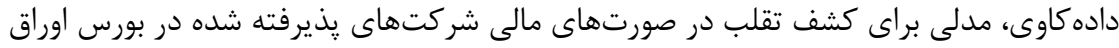

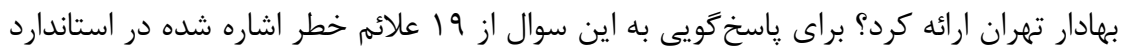

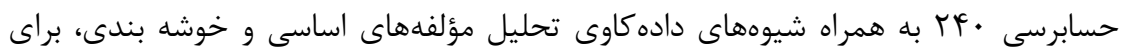

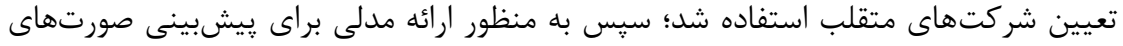

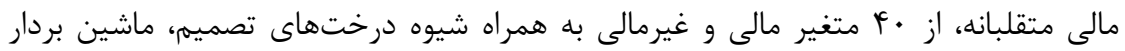

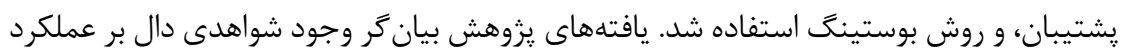

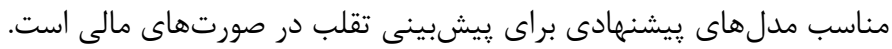

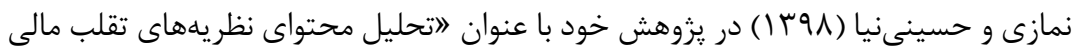

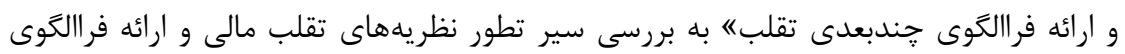

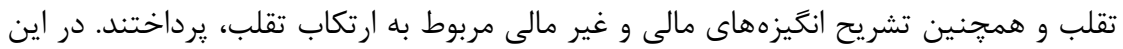

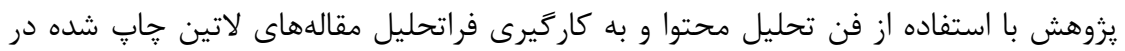

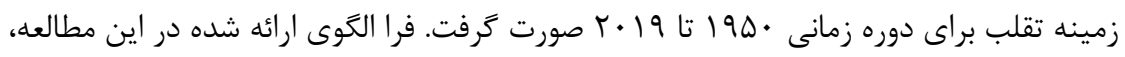
داراى ابعاد مالى و غيرمالى است و در جهار دسته كلى شرايطى، موقعيتى، هنجارى و و هوش

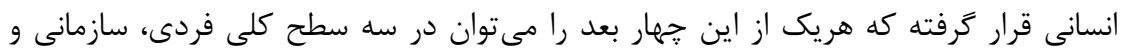

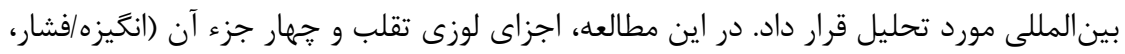

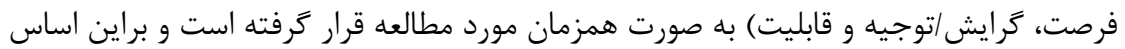
فرالكويى جامع ارائه شد. r- بوالات يثروهش

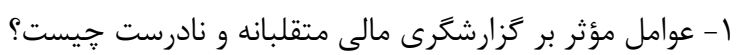

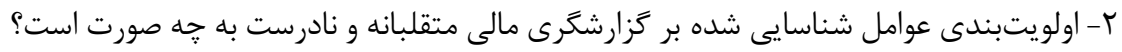

\section{F-روش شناسى يزوهش}

اين يزوهش از نظر هدف اكتشافى مى باشد و از نظر شيوه كردآورى و تحليل اطنالاعات، اين

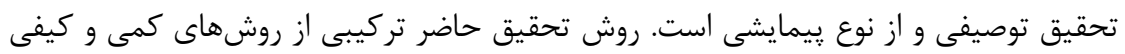


است. در اين يزوهش ابتدا به رويكرد كيفى و سيس كمى يرداخته شده است. براى حل مسئله

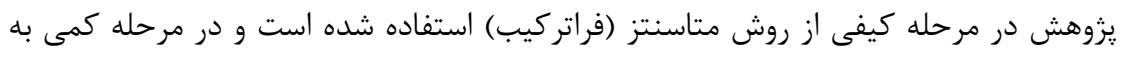

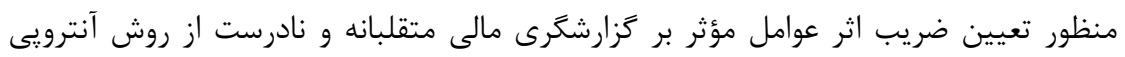
شانون استفاده شده است.

يكى از روشهايى كه به منظور بررسى و تركيب و آسيب شناسى مطالعات ييشين در جند سال كذشته معرفى شده است، فرا مطالعه'است. فرا مطالعه يك تجزيه و تحقيق عميق از كارهاى

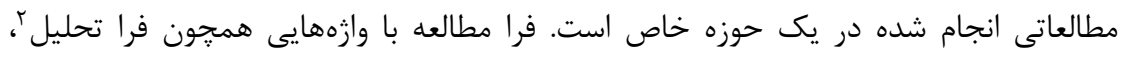

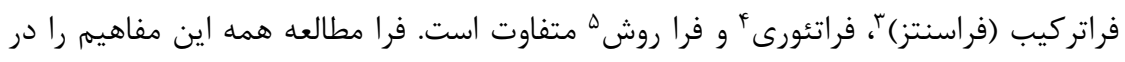
برمى گيرد. فرا مطالعه اتر به صورت كيفى و روى مفاهيم مورد استفاده در مطالعات كذشته انجام كيرد، به نام فراسنتز يا فراتركيب شناخته ميىشود. فراتركيب در واقع تركيب، تحليل و تفسير

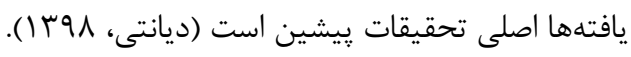

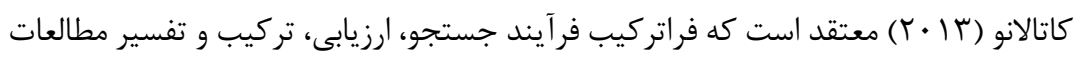
كمى يا كيفى در يك حوزه خاص است. در كل سه هدف اصلى براى فراتركيب بيان شده كه

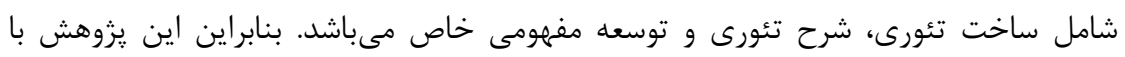
به كاركيرى فراتركيب درصدد شناسايى عوامل مؤثر و اجزاى دخيل در يديده تقلب و واشتباه است.

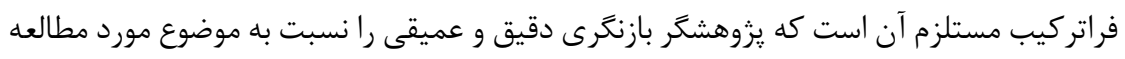

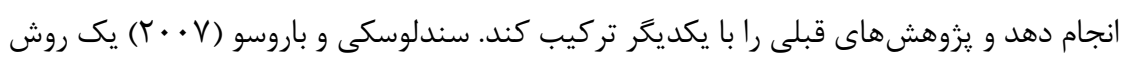
V مرحلهاى براى تحقيقات فراتركيب ارائه دادهاند.

كام اول: تنظيم سوال يزوهش

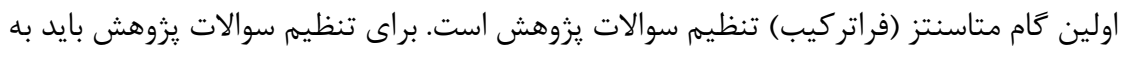
موارد زير توجه كرد:

${ }^{1}$ Meta-Study

${ }^{2}$ Meta-Analysis

${ }^{3}$ Meta-Synthesis

${ }^{4}$ Meta-Theory

${ }^{5}$ Meta-Method 


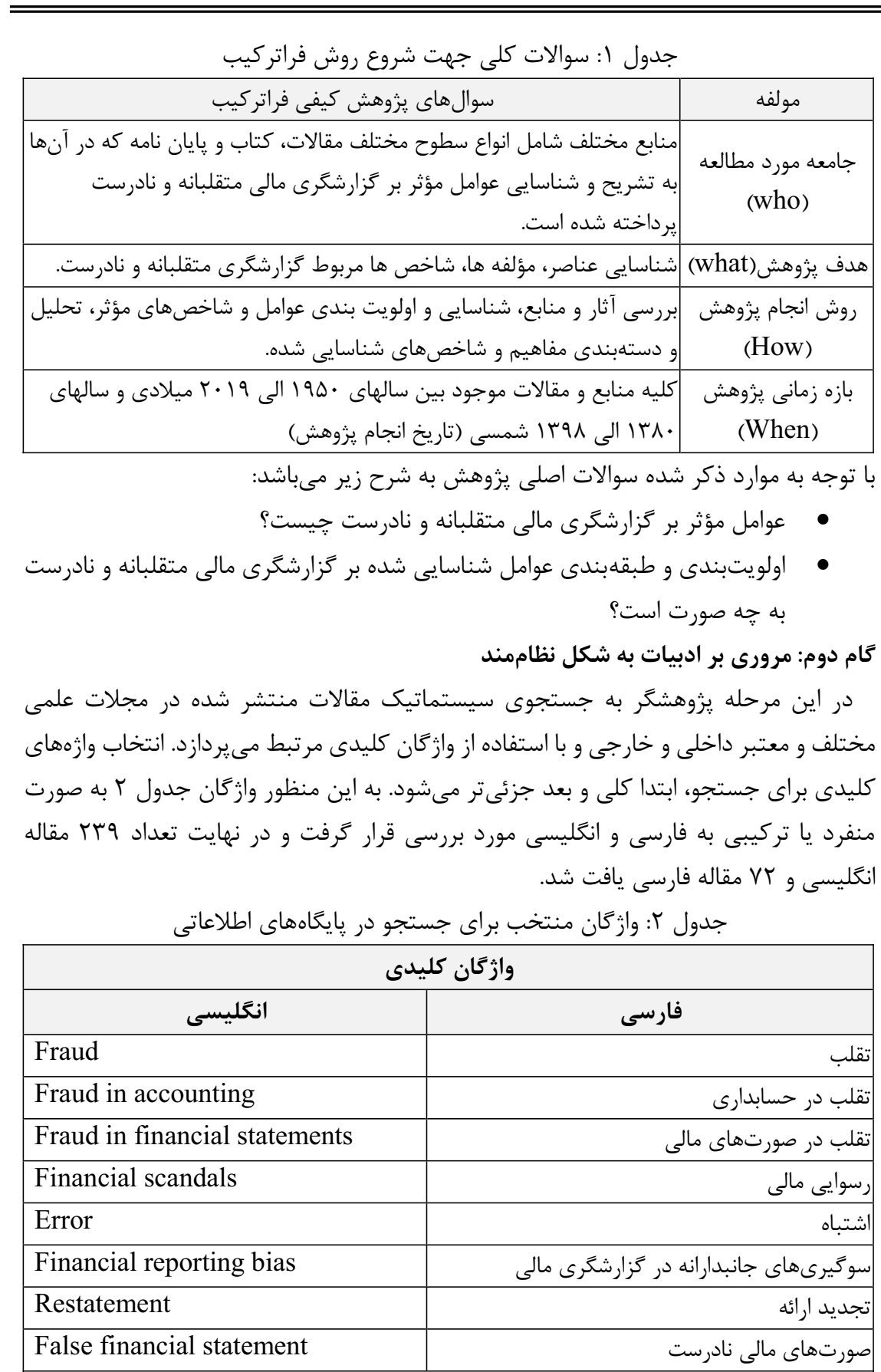




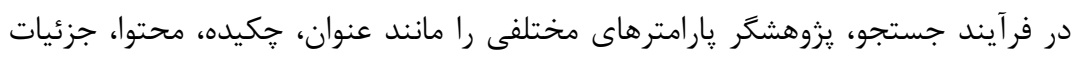

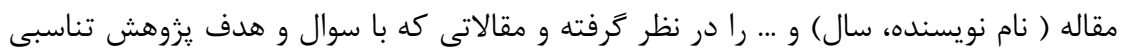

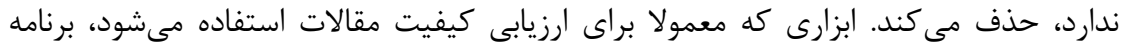

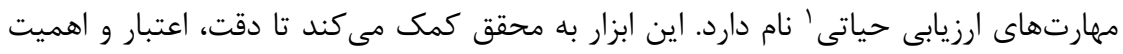

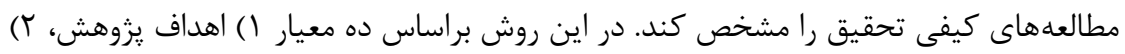

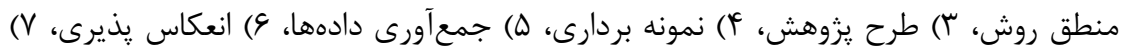

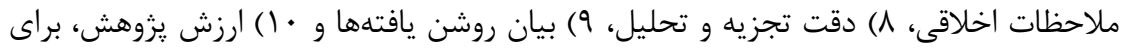

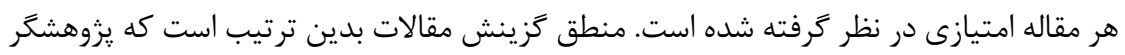

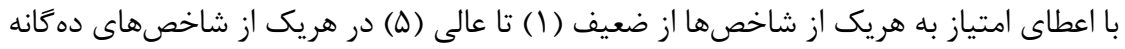

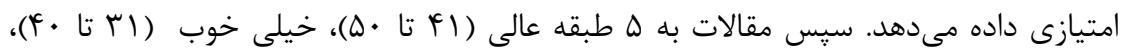

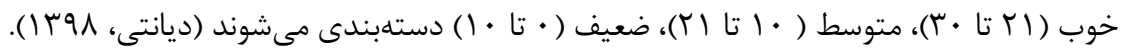

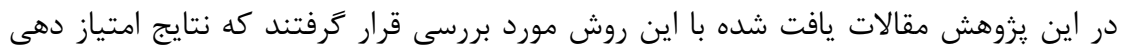

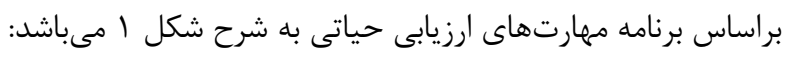

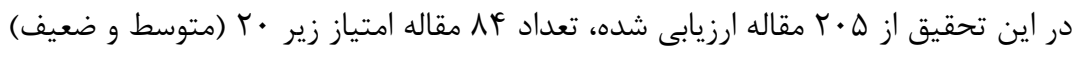

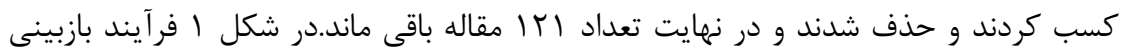

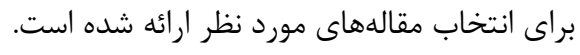

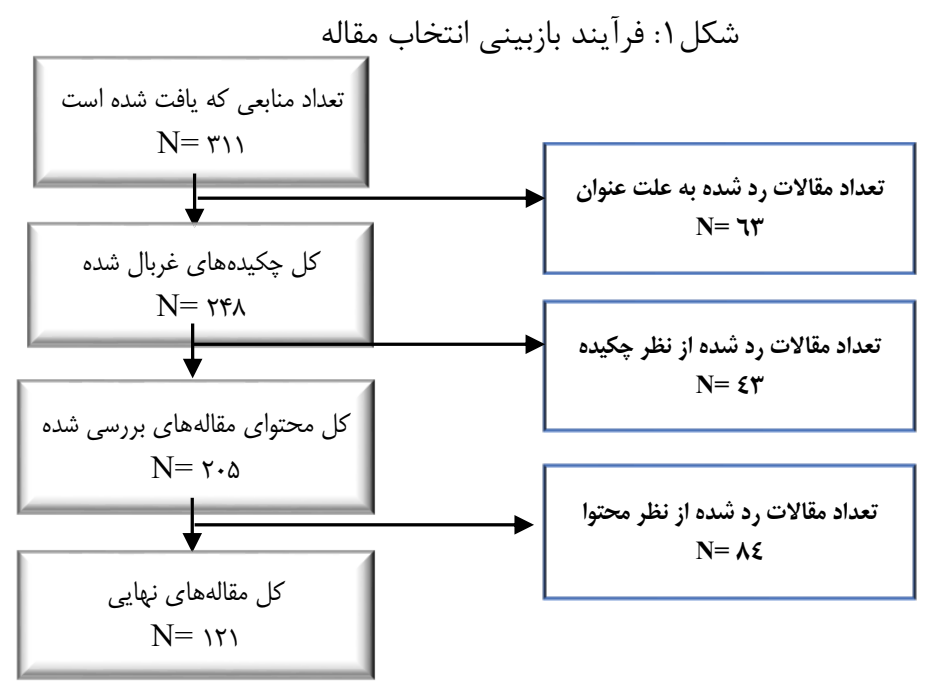

${ }^{1}$ Critical appraisal skills program (CASP) 


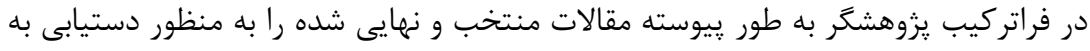
يافتهاى درون محتواهاى مجزايى كه در آنها مطالعات اصلى و اوليه انجام شدهاند، جندئد

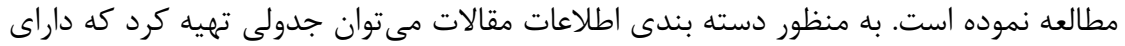

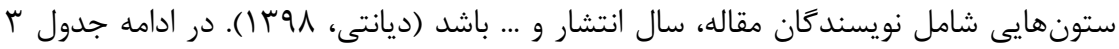

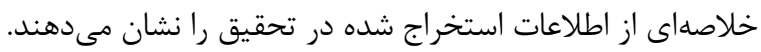

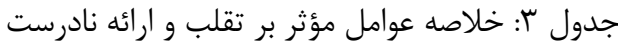

\begin{tabular}{|c|c|}
\hline نويسندگًان - سال انتشار & عوامل موثر بر تقلب \\
\hline 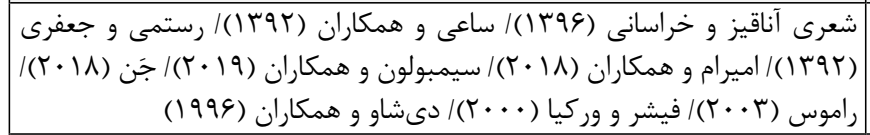 & شرايط بازار سرمايه \\
\hline 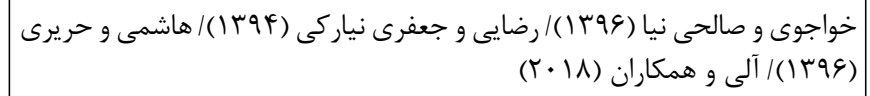 & كيفيت و مبلغ اقلام \\
\hline 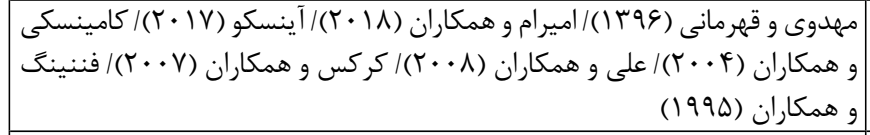 & مشكلات اقتصاد كلان \\
\hline 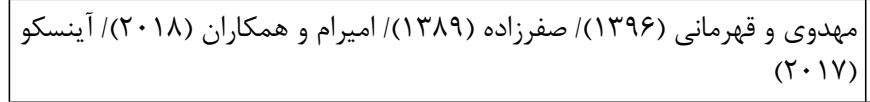 & شرايط سياسى و \\
\hline 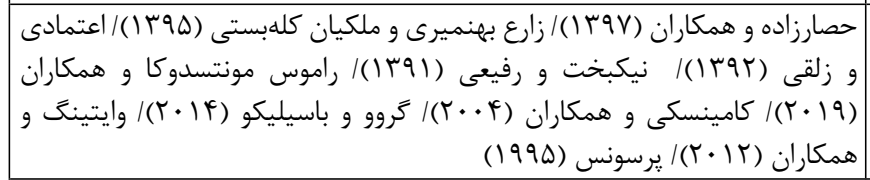 & اهرم هاى مالى \\
\hline 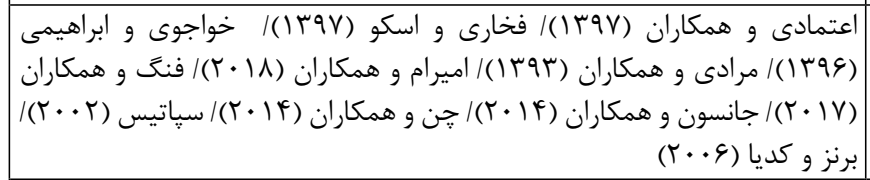 & ارزش و بازده سهام و \\
\hline 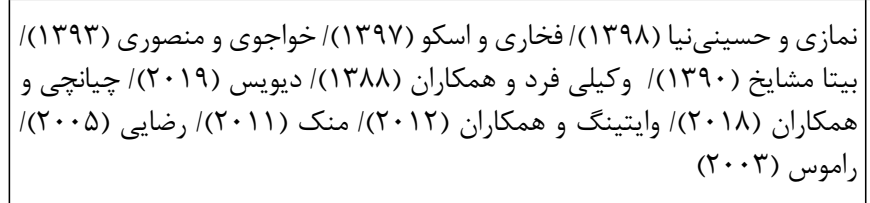 & 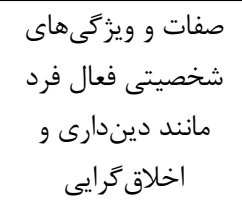 \\
\hline 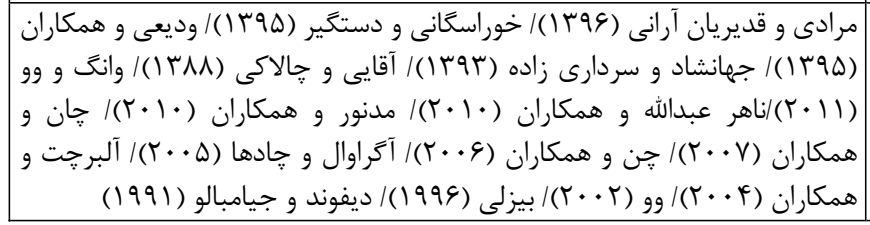 & ساختار مالكيت شركت \\
\hline
\end{tabular}




\begin{tabular}{|c|c|}
\hline 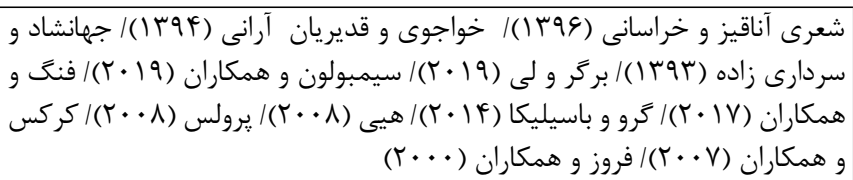 & كاهش سودآورى و \\
\hline 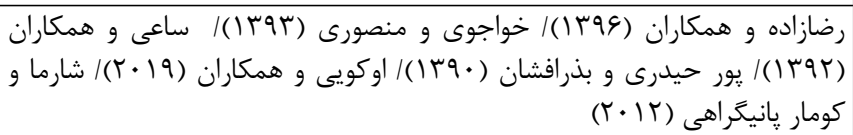 & معاملات غيرعادى و \\
\hline 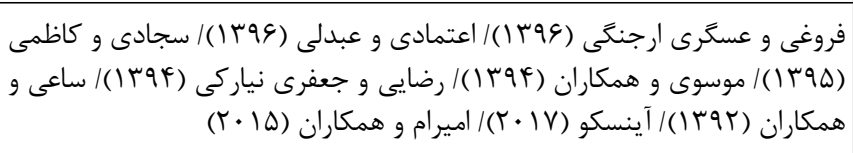 & شيوه پِياده سازى و \\
\hline 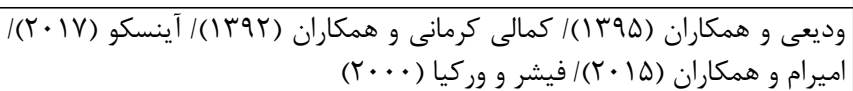 & شيوه هاى مديريتى \\
\hline 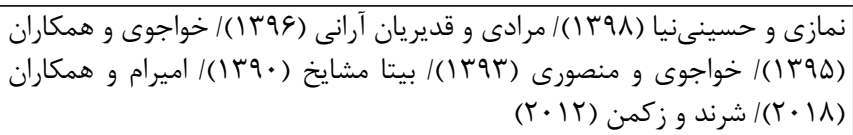 & 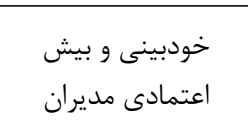 \\
\hline 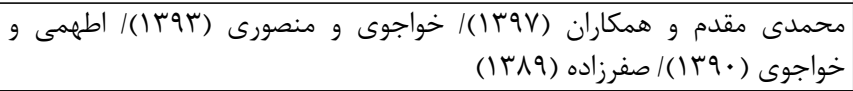 & 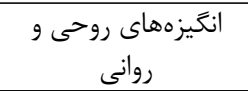 \\
\hline 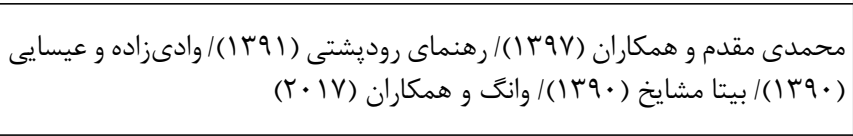 & 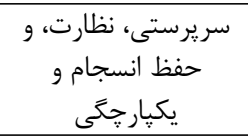 \\
\hline 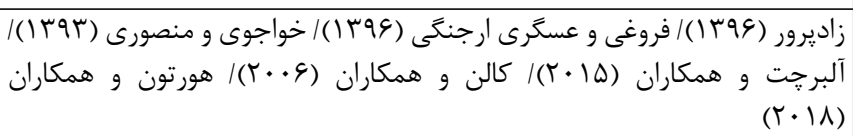 & رفتارهاى غير قانونى \\
\hline 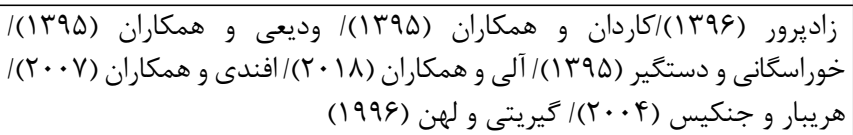 & $\begin{array}{l}\text { كسب منابع مالى و افزايش } \\
\text { سرمايه }\end{array}$ \\
\hline 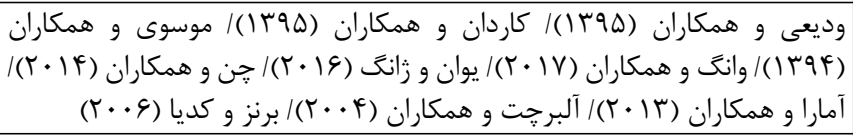 & 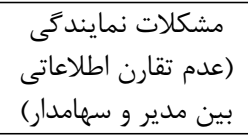 \\
\hline 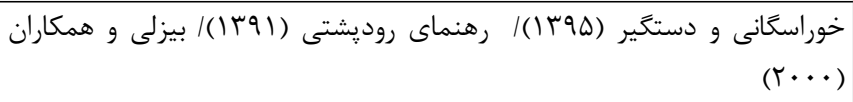 & كنترل مالكين \\
\hline 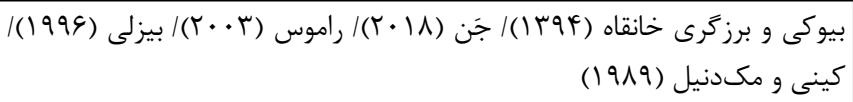 & وجود كميته \\
\hline 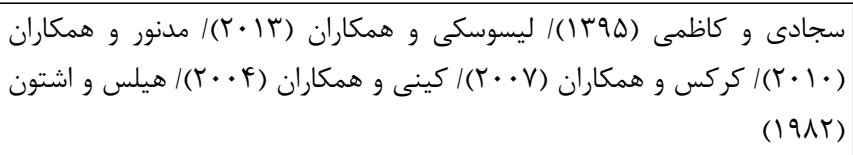 & مقاصد مالياتى \\
\hline
\end{tabular}




\begin{tabular}{|c|c|}
\hline 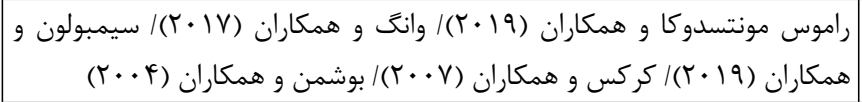 & 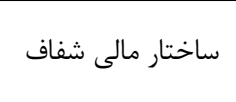 \\
\hline 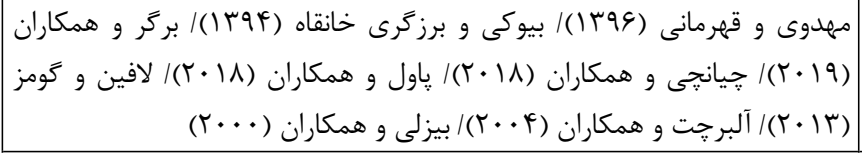 & ضعف نظارت خارج از \\
\hline 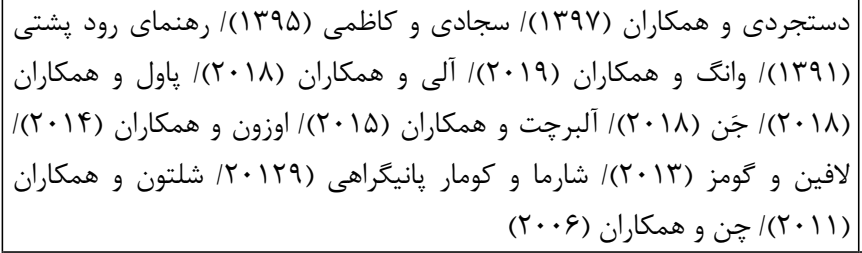 & نظام قانونى و قوانين و \\
\hline 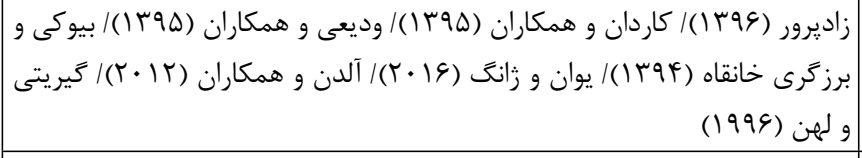 & جذاب منابع تامين دستر و \\
\hline 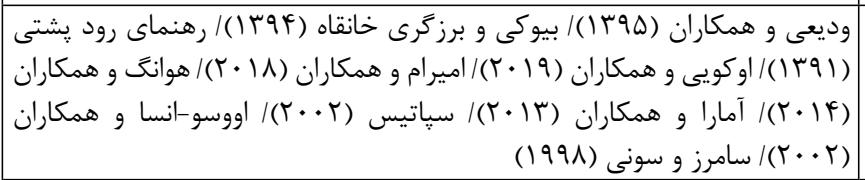 & زيان و مشكلات \\
\hline 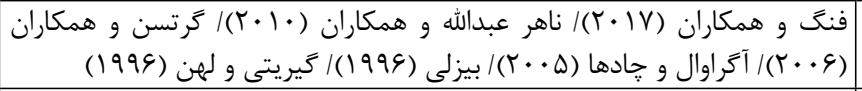 & تر كيب هيأت مديره \\
\hline 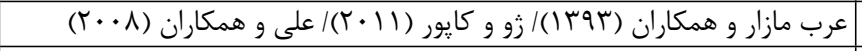 & ي يششرفت تكنولوزى \\
\hline 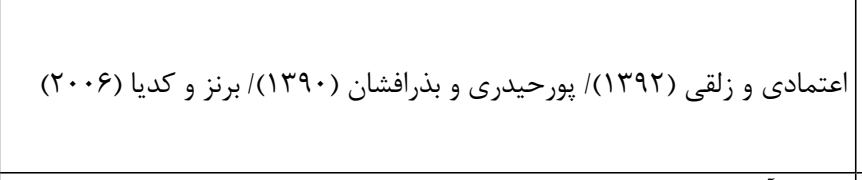 & 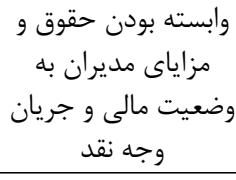 \\
\hline 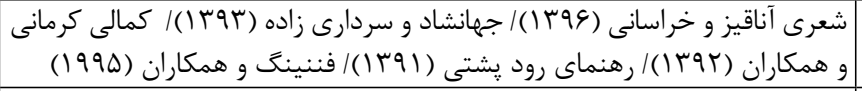 & نوع صنعت \\
\hline 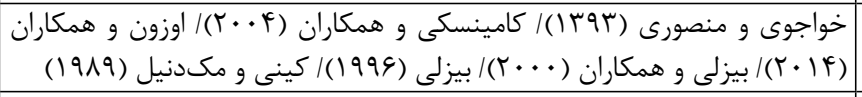 & 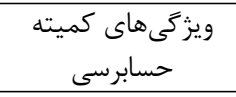 \\
\hline 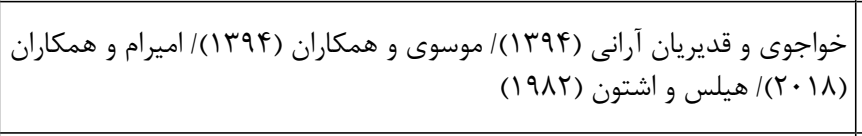 & توسطبات رياضى سيستم از اشتى انسان \\
\hline 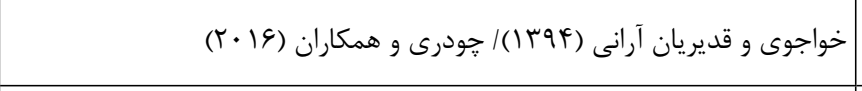 & وتخمين در محاسبه از برآد \\
\hline 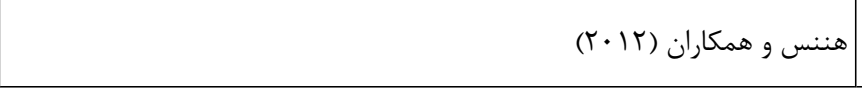 & 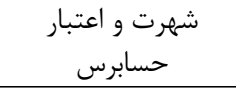 \\
\hline
\end{tabular}




\begin{tabular}{|c|c|}
\hline 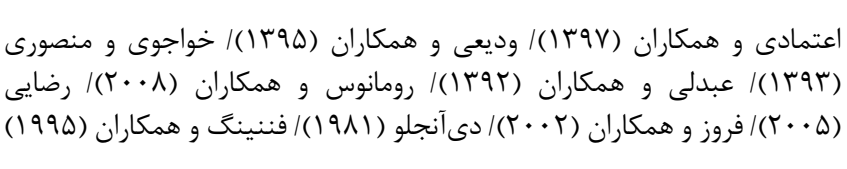 & 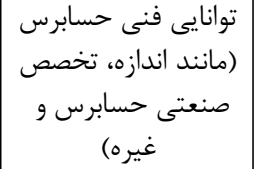 \\
\hline 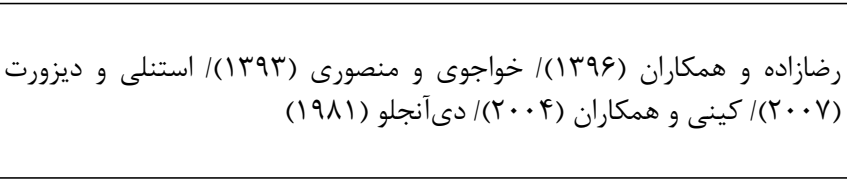 & وجود استقلال براى \\
\hline 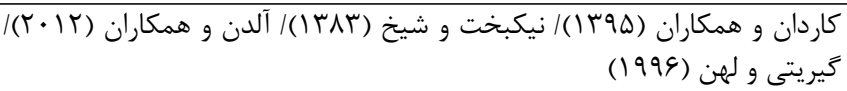 & 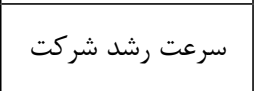 \\
\hline 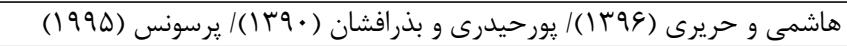 & تركيب دارايىها \\
\hline 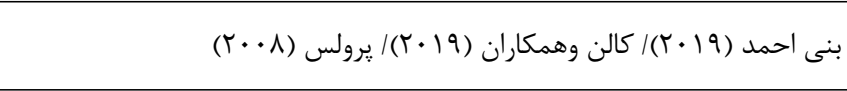 & امنيت سيستمهاى \\
\hline 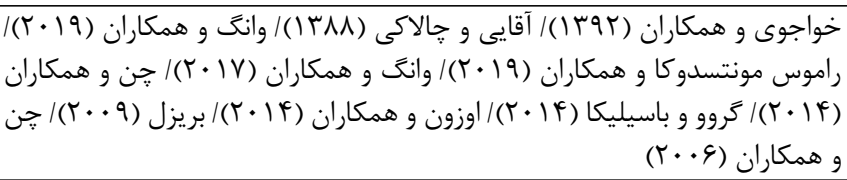 & 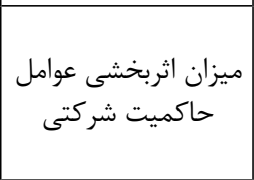 \\
\hline 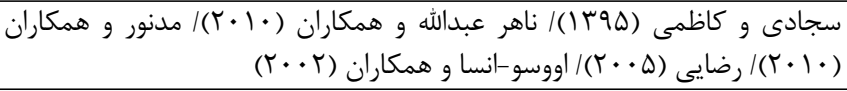 & كيفيت حسابرسى \\
\hline 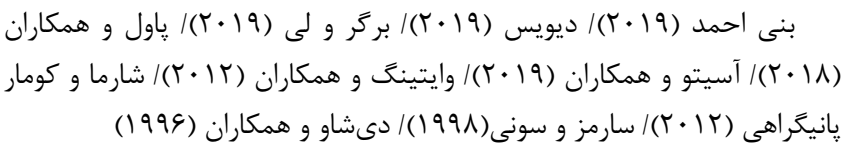 & كنترلهاى داخلى ضعف \\
\hline
\end{tabular}

ه- يافته هاى يزوهش

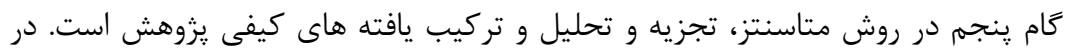
طول تجزيه و تحليل، موضوعها يا تمهايى جستجو مى شود كه در ميان مطالعات موجود در دران

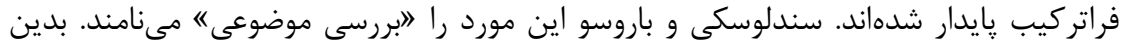

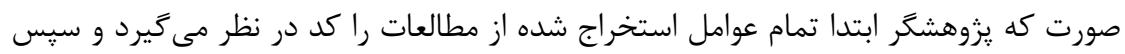

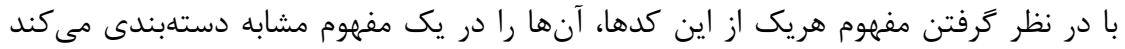

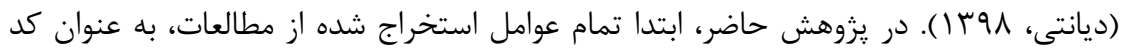

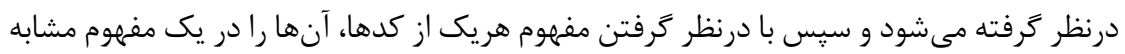
دستهبندى مىشوند كه در جدول V به طور خلاصه نشان داده شدهاست. 


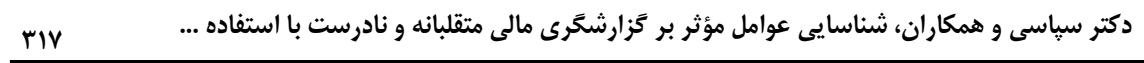

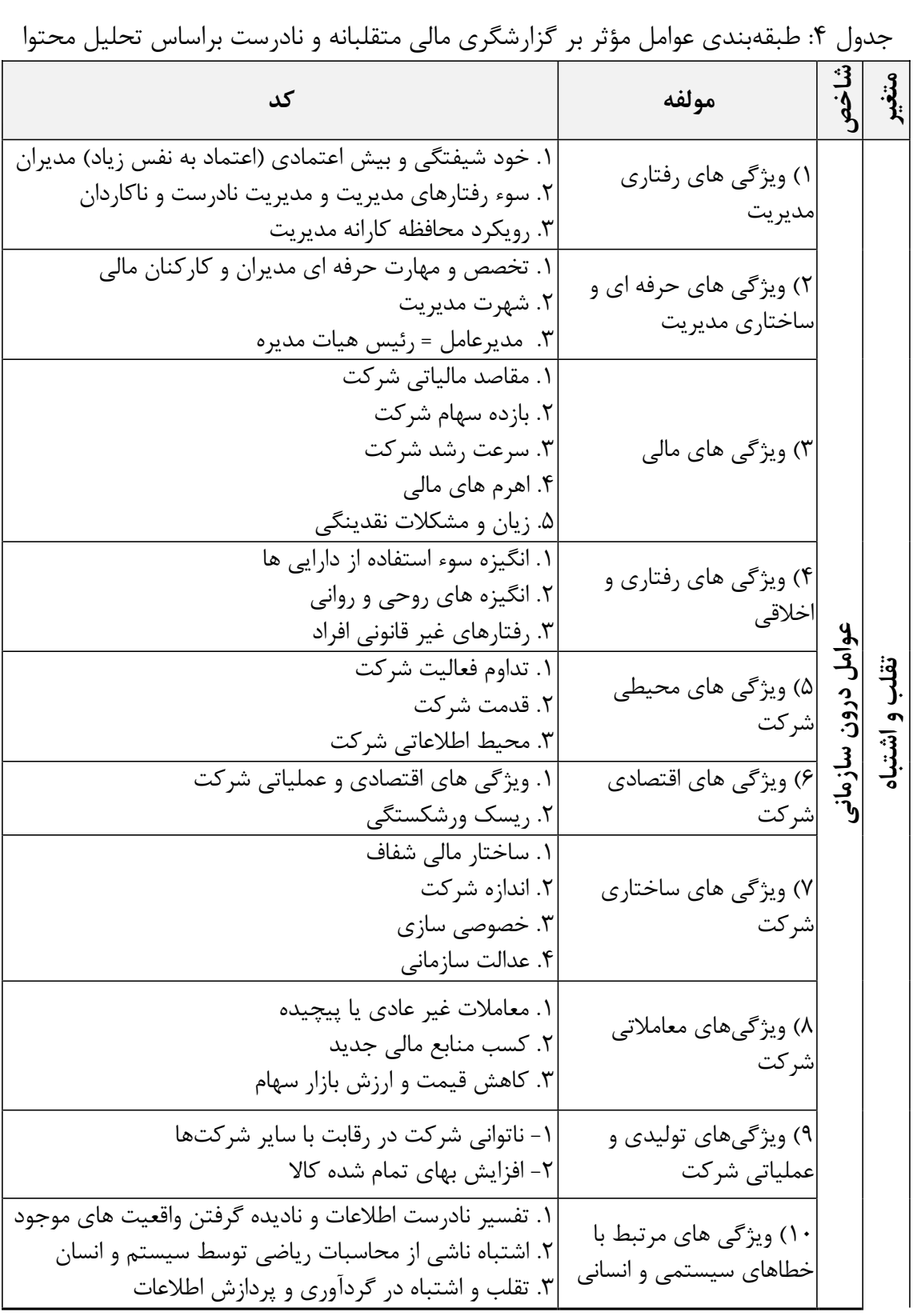


دو فصلنامه حسابدارى ارزشى و رفتارى، سال ينجم، شماره نهم، بهار و تابستان 99"1

\begin{tabular}{|c|c|c|c|}
\hline 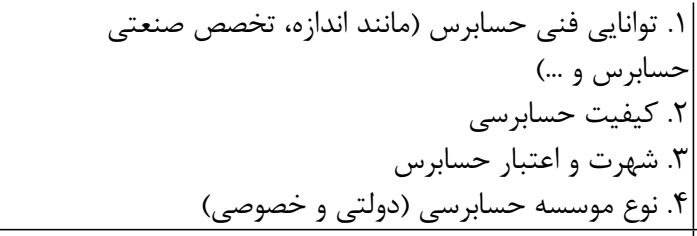 & هاى حسابرسى مستقل مرتبط با ويزگى & \multirow{7}{*}{ 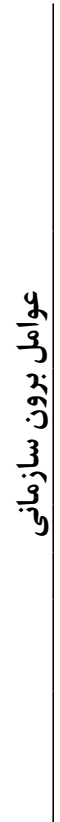 } & \multirow{7}{*}{ 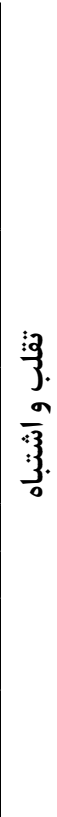 } \\
\hline 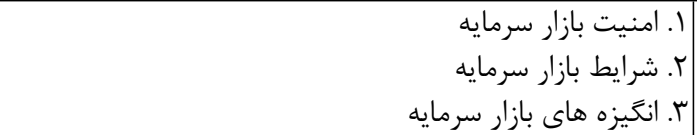 & سرمايه (T) عوامل مربوط به بازار & & \\
\hline 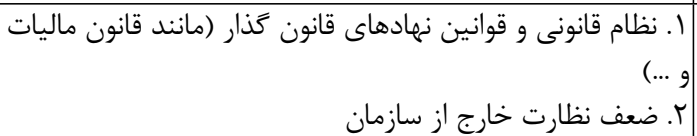 & خارج از سازمان & & \\
\hline |. فرهنگ عمومى (هنجارهاى اجتماعى، عقايد، باورها و ...) & |( ) عوامل فرهنكى & & \\
\hline |. شرايط سياسى و اجتماعى حاكم بر محيط هاى اقتصادى & ل) عوامل سياسى & & \\
\hline (. مشكلات اقتصاد كلان (مانند ركود و بحران) & (9) عوامل اقتصادى برون & & \\
\hline 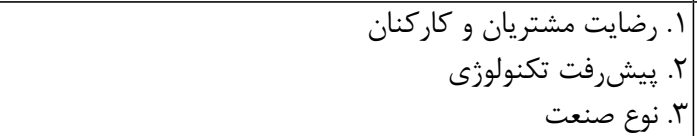 & 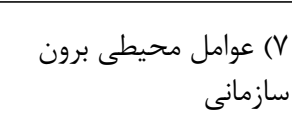 & & \\
\hline
\end{tabular}

\section{كام ششم: كنترل كيفيت و تحليل محتوا}

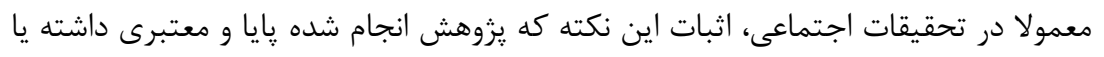

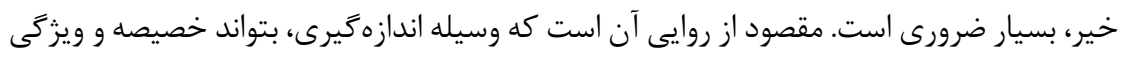

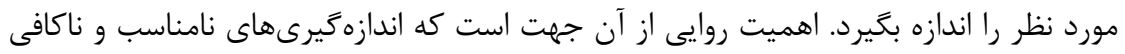

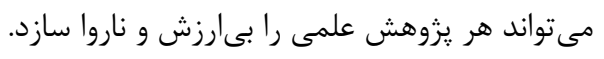

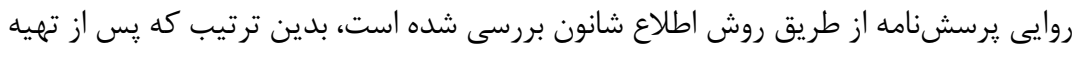

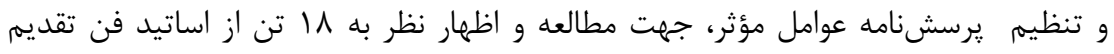

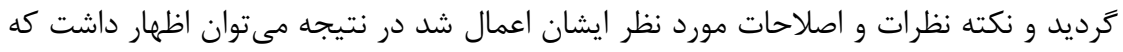
يرسشنامه از روايى مناسب برخوردار است نيات

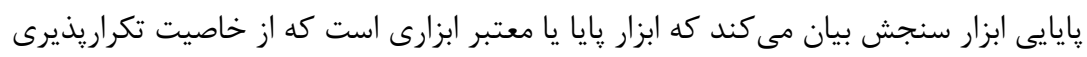

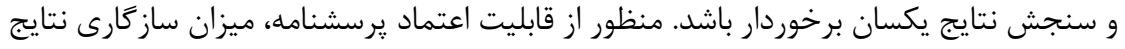

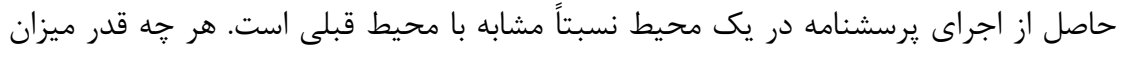

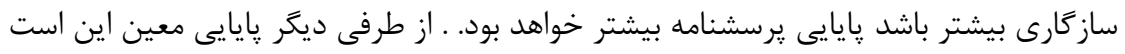

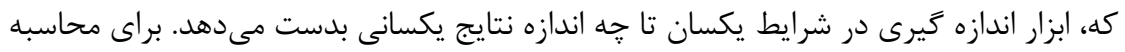


ضريب يايايى در اين يزوهش از روش آلفاى كرونباخ استفاده شده است. نتايج پايايى خرسشنامه به شرح جدول ه مىباشد.

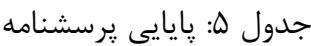

\begin{tabular}{|c|c|}
\hline ضر سوالات در زمينه تقلب كرونباخ كل & 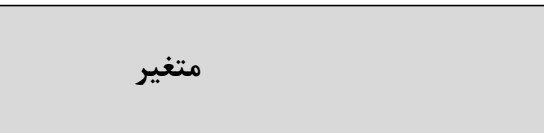 \\
\hline.$\Delta T V$ & ويزَكى هاى مديريتى شركت \\
\hline. $.1 T Y$ & ويزَى هاى مالى \\
\hline $.99 \mathrm{~V}$ & ويزَىى هاى رفتارى و اخلاقى \\
\hline .990 & ويزَّى هاى محيطى شركت \\
\hline $.9 \vee 9$ & ويزگى هاى اقتصادى شركت \\
\hline - ret & ويزگى هاى ساختارى شركت \\
\hline.$\Delta T \Delta$ & ويزگى هاى معاملاتى \\
\hline.$\Delta 9 \Delta$ & ويثگى هاى توليدى و عملياتى شركت \\
\hline$\cdot . \mathrm{V} \cdot \mathrm{V}$ & ويزگگى هاى كنترلى و نظارتى درون سازمانى \\
\hline. .111 & ويزّكى هاى مرتبط با خطاهاى سيستمى و انسانى \\
\hline$\cdot . \mathrm{VIT}$ & ويزگكى هاى سيستم هاى اطلاعاتى و حسابدارى \\
\hline$\cdot . r \cdot 9$ & عوامل مرتبط با ويزگگى هاى حسابرسى مستقل \\
\hline .999 & عوامل مربوط به بازار سرمايه \\
\hline$\cdot . r \cdot 4$ & عوامل قانونى و نظارتى خارج از سازمان \\
\hline.$\Delta T V$ & عوامل فرهنگَى و سياسى واقتصادى برون سازمان \\
\hline.$\Delta F 1$ & عوامل محيطى برون سازمانى \\
\hline$\cdot .9 r \Delta$ & عوامل درون سازمانى \\
\hline. .999 & عوامل برون سازمانى \\
\hline $.9 F F$ & يايايى \\
\hline
\end{tabular}

ضرايب بالاى V. • براى آلفاى كرونباخ بيانكر هايايى ابزار مىباشد. با توجه به نتايج عنوان شده

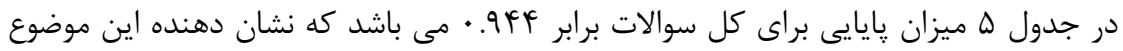

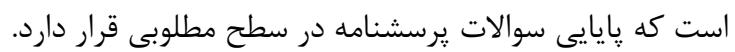
تحليل محتوا مرحلهاى از فرآيند اطلاعاتى است كه از طريق آنداني

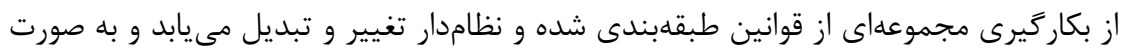

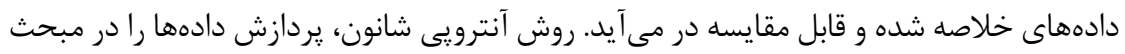
تحليل محتوا بسيار قوى انجام مى دهدد. 
در اين يزوهش كاو عامل مؤثر بر تقلب و اشتباه شناسايى شده در مراحل قبل به صورت خك

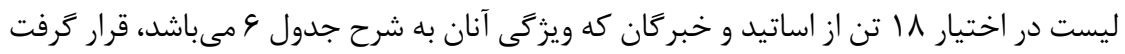

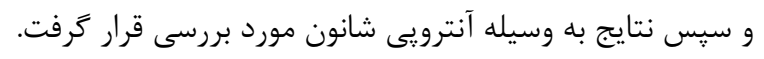
جدول צ: ويزگى خبر كان

\begin{tabular}{|c|c|}
\hline تعداد & ويزگى خبر كان \\
\hline 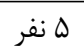 & اساتيد دانشكاه \\
\hline 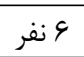 & مديران سازمان حسابرسى \\
\hline 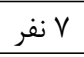 & اعضا كميته تحقيقات و تدوين استانداردهاى سازمان حسابرسى \\
\hline 1) انفر & جمع \\
\hline
\end{tabular}

Fامهاى آنترويى شانون انجام شده در اين يزوهش به شرح زير مىباشد:

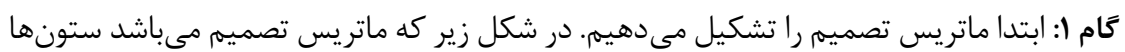
معيار و سطرها كزينهها هستند. به عنوان مثال درايه 12 Xامتياز تزينه اول نسبت به معيار دوم

$$
X=\left[x_{i j}\right]=\left[\begin{array}{ccc}
x_{11} & \cdots & x_{1 m} \\
\vdots & \ddots & \vdots \\
x_{n 1} & \cdots & x_{n m}
\end{array}\right]
$$

كام r: ماتريس بالا رانرمال مى كنيم و هر درايه نرمال شده راز

$$
\text { صورت مىباشد كه درايه هر ستون را بر مجموع ستون تقسيم مى كنيم. }
$$

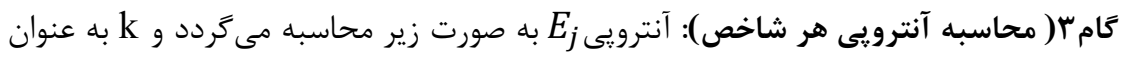

$$
\begin{aligned}
& E_{j}=-k \sum_{i=1}^{m} p_{i j} \ln \left(p_{i j}\right) i=1.2 \ldots . m \\
& k=\frac{1}{\ln (m)} \cdot \text { كه در آن }
\end{aligned}
$$

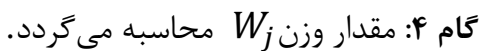

$$
\begin{aligned}
& W_{j}=\frac{E_{j}}{\sum_{i} E_{i}}
\end{aligned}
$$

برمبناى اين روش شاخصى كه بيشترين وزن را دارد بيشترين نقش در شاخص اشتباه يا تقلب

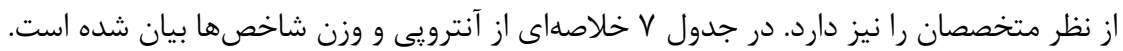




\begin{tabular}{|c|c|c|c|c|c|c|}
\hline \multicolumn{7}{|c|}{ جدول V: آنترويى شانون } \\
\hline \multicolumn{3}{|c|}{ تقلب } & \multicolumn{3}{|c|}{ اشتباه } & \multirow[t]{2}{*}{ ت ت ت أثير } \\
\hline رتبه & $W_{j}$ & $E_{j}$ & 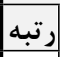 & $W_{j}$ & $E_{j}$ & \\
\hline KF & $\because .1 \cdot 9$ & .909 & $r \cdot$ & $\because .14$ &.$\wedge r \cdot$ & شرايط بازار سرمايه \\
\hline iv & $\because \cdot 1 \cdot 9$ & $.9 \mu \mathrm{v}$ & $\Delta \Lambda$ & $\because .11$ & $\cdot .119$ & مشكلات اقتصاد كلان (ركود وبحران) \\
\hline iv & $\because \cdot 1 \cdot 9$ & $.9 \mathrm{rv}$ & $\Delta 9$ & $\because \cdot 1 \cdot$ & $.9 \mathrm{VN}$ & 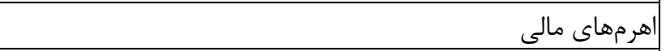 \\
\hline$\wedge$ & $\cdot .111$ & $\cdot .91 \cdot$ & 91 & $\because \cdots 9$ & $\cdot .94 \cdot$ & |ساختار مالكيت شركت \\
\hline iv & $\because \cdot 1 \cdot 9$ & $.9 \mathrm{rv}$ & ft & $\because .14$ & -. . १ V & معاملات غيرعادى يا پييجيده \\
\hline $9 V$ & $\because \cdot 1 \cdot \mathrm{F}$ &. $.91 \%$ & ra &. .14 & $\cdot . \wedge 9 \cdot$ & خودشيفتتى و بيشاعتمادى مديران \\
\hline$\wedge$ &. .111 & $\cdot .91 \cdot$ & 11 &. .14 & $\cdot . \Lambda \Lambda \mathrm{V}$ & ويثزى هاى مديريت و نفوذ آن بر محيط كنترلى \\
\hline 1 &. .114 & $1 . \cdots$ & $\wedge \vee$ & $\because \cdots 4$ & $\cdot r \wedge \cdot$ & رفتارهاى غير قانونى افراد \\
\hline rF & $\because \cdot 1 \cdot 9$ & .909 & 11 &. .14 & $.91 \%$ & وجود كميته حسابرسى \\
\hline VV & $\cdot \cdot \cdot 1 \cdot 1$ & $\cdot . \wedge \wedge \vee$ & r & $\because \cdot 1 f$ & $\cdot .91 \cdot$ & 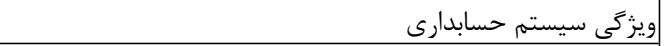 \\
\hline iv & $\because \cdot 1 \cdot 9$ & $.9 \mathrm{rv}$ & 91 & $\because \cdots 9$ &. .94. & انغَيزهها و وابستخى مذهبى و سياسى \\
\hline TF & $\because .1 \cdot 9$ & .909 & f & $\because .14$ & .909 & ضعف نظارت خارج از سازمان \\
\hline$\Lambda$ & $\because \cdot 111$ & $.91 \cdot$ & fq & $\because \cdot 11$ & $\cdot .119$ & نظام قانونى و قوانين و مقررات \\
\hline$\Lambda$ & $\cdot .111$ & $.91 \cdot$ & 91 & 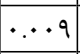 & $\cdot .94 \cdot$ & فرهنگ عمومى \\
\hline$\Lambda$ &. .111 & $.91 \cdot$ & $\wedge 1$ & $\cdots \mathrm{V}$ & $\cdot .+\wedge \cdot$ & زيان و مشكلات نقدينكى \\
\hline$\Lambda$ &. .111 &. $.91 \cdot$ & FT & $\because .14$ &. . จ V & شهرت مديريت \\
\hline 1 & $\because \cdot 11 \mathrm{f}$ & $1 \ldots$ & 11 & $\because \cdot \mathrm{V}$ & 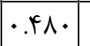 & قراردادهاى غيرعادى يا جانبدارانه \\
\hline$\wedge$ &. .111 & $\cdot .91 \cdot$ & 49 & $\because .11$ &. .119 & مديرعامل = رئيس هيأت مديره \\
\hline 1 &. .114 & $1 . \cdots$ & 94 & $\because \cdots$ & $\because \cdots$ & انغيزه سوء استفاده از دارايىها \\
\hline$\Lambda$ &. .111 & .91 . & FT &. .14 & $\cdot . \vee 9 \vee$ & ويزگ هاى اقتصادى و عملياتى شركت \\
\hline 1 & $\because \cdot 11 \mathrm{f}$ & $1 . \cdots$ & 9 . & 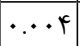 & - TY. & وابستگى مالى صاحبكار \\
\hline 94 & $\because \cdots \vee$ &. $.9 \mathrm{VY}$ & 1 &. .10 & $1 \ldots$ & اشتباه ناشى از محاسبات رياضى \\
\hline$\wedge 9$ & $\because \cdots 91$ &.$\wedge 9$. & 9 & $\because .14$ & $\cdot .9 \mathrm{rv}$ & تفسير نادرست اطلاعات و واقعيت \\
\hline GV & $\because \cdot 1 \cdot \mathrm{F}$ & $.91 \%$ & r & $\because .14$ & .909 & استفاده از رويههاى حسابدارى متفاوت و همجنين تغيير در رويهها \\
\hline$\wedge \varepsilon$ & $\because \cdots 91$ & $\cdot . \wedge 4$. & $r$ &. .14 & $.91 \cdot$ & |ستفاده از برآورد و تخمين در محاسبه \\
\hline $9 V$ & $\cdot \cdot \cdot \cdot+4$ & $.91 \%$ & i &. .14 & $\cdot .909$ & تعداد زياد تكنيكهاى اندازهيرى \\
\hline 91 & $\because 99 \mathrm{f}$ & $\cdot . \wedge r$. & i &. .14 & .909 & كاربرد يا تفسير نادرست استانداردها \\
\hline iv & $\because .1 \cdot 9$ & $.9 \mathrm{rv}$ & r &. .14 & .909 & ميزان اثربخشى عوامل حاكميت \\
\hline$\Lambda$ &. .111 & $.91 \cdot$ & $r \Delta$ &. .14 & $\cdot . \wedge 9 \cdot$ & نقاط ضعف و كمبودهاى ساختارى \\
\hline$\Lambda$ &. .111 & $.91 \cdot$ & $r \cdot$ &. .11 & $\cdot . \Lambda r \cdot$ & وجود فشارهاى غيرعادى درونى \\
\hline$\Lambda$ &. .111 &. $.91 \cdot$ & 9 &. .14 & $.9 \mathrm{rv}$ & ضعف كنترلهاى داخلى \\
\hline$\Lambda$ &. .111 & $\cdot .91$. & Ir &. .14 & $.91 \%$ & تغييرات ساختارى در شركت \\
\hline 1 & $\cdot .111 \mathrm{f}$ & $1 . \cdots$ & $r \cdot$ &. .14 & $\cdot . \Lambda \mu \cdot$ & سوء رفتارهاى مديريت \\
\hline$\wedge$ & $\cdot .111$ & $.91 \cdot$ & 11 &.. .14 & $\cdot . \wedge \wedge \vee$ & كيفيت حسابرسى \\
\hline
\end{tabular}


ايده اصلى روش آنترويى شانون اين است كه هر جهه وزن يك شاخص بيشتر باشد آن شاخص

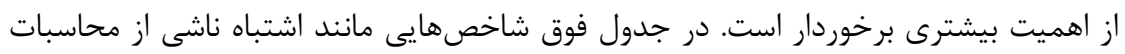

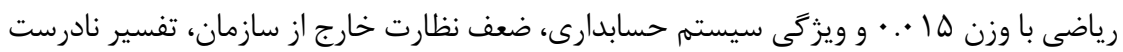

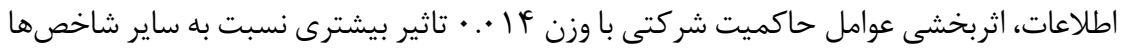
بر تقلب و ارائه نادرست در صورتهاى مالى دارند. همجنين عوامئلى

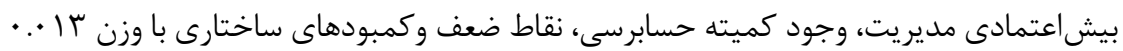

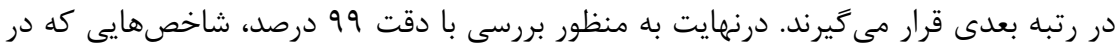

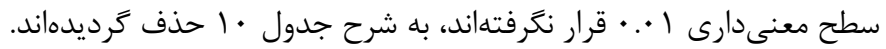

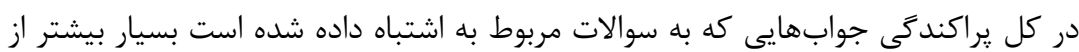

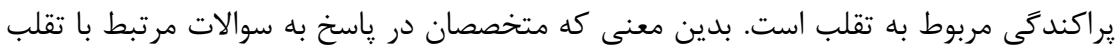

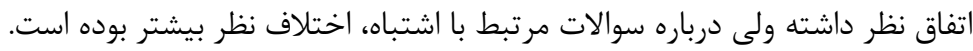
كام هفتم: ارائه يافتهها در اين مرحله از فراتركيب، يافتههاى حاصل از مراحل قبل ارائه مىشوند واند و يافتههاى يزوهش

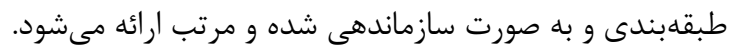

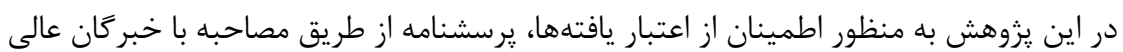

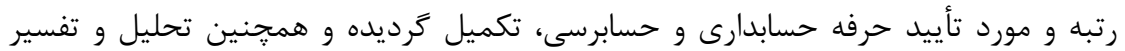

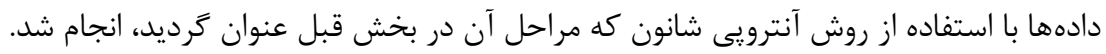

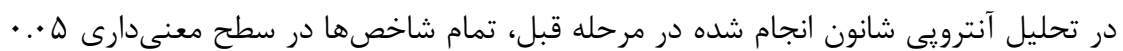

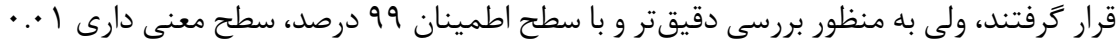

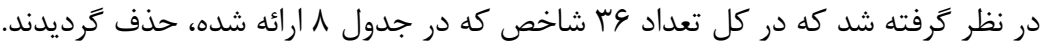
جدول م: شاخصهاى حذف شده بعد از تحليل آنترويى شانون آندان

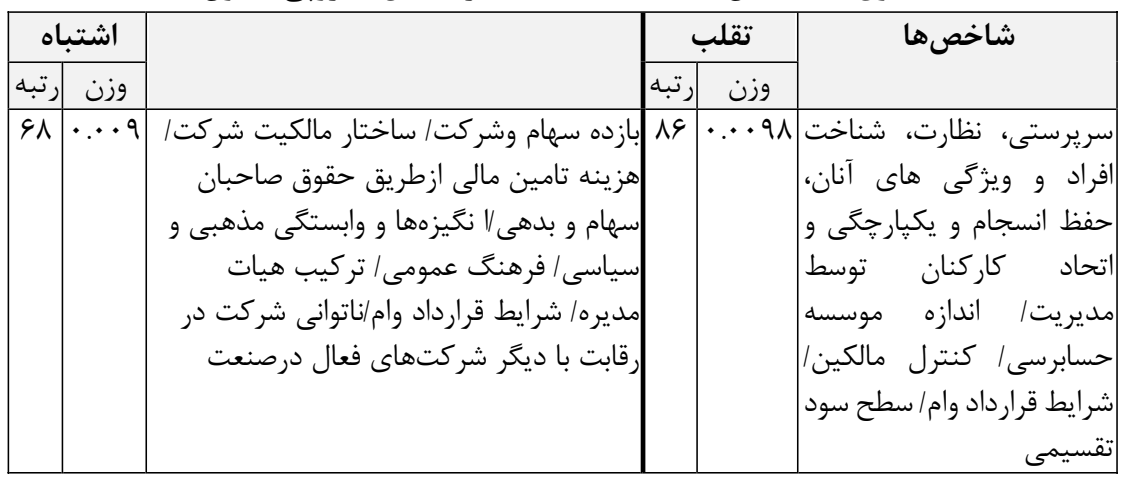




\begin{tabular}{|c|c|c|c|c|c|}
\hline & & زارشَّرى مالى متقلبانه و نادرست با استفاده & & 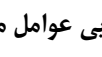 & و همكار ان، شنا, \\
\hline VG & $\because \cdots \wedge$ & 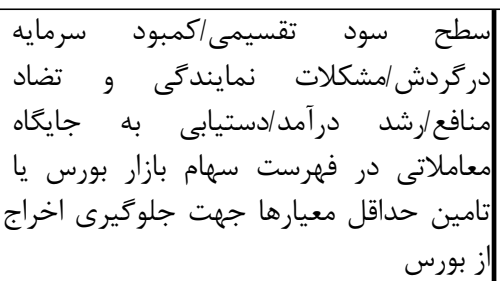 & 91 & $\because \cdots 94$ & | استاربرد \\
\hline 11 & $\because \cdots V$ & 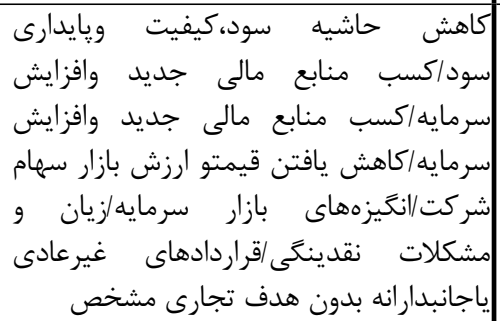 & $9 \pi$ & $\because \cdots 9$ & 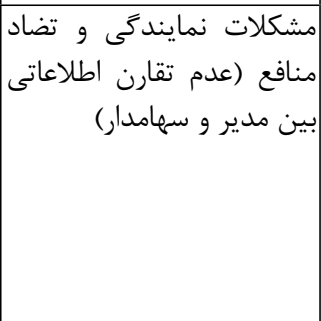 \\
\hline$\Lambda \mathrm{V}$ & $\because .94$ & 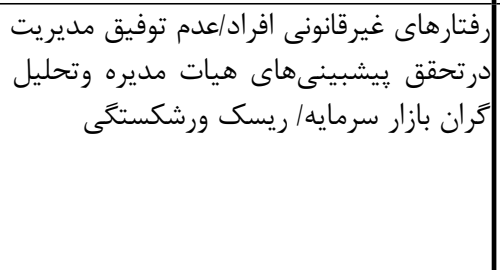 & 94 & $\because \cdot \vee 9$ & 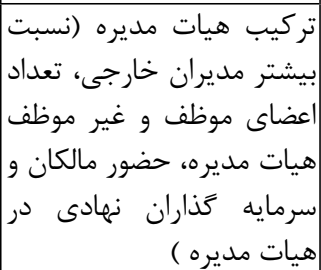 \\
\hline $9 \cdot$ & $\because \cdots 4$ & 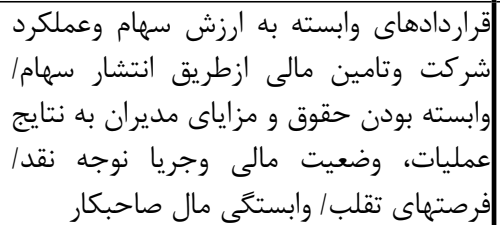 & & & \\
\hline 94 & & انخخيزه سوء استفاده از دارايىها & & & \\
\hline
\end{tabular}

\section{9-نتيجه}

تقلب مالى در عمليات تجارى و بازار سرمايه، به علت تأثيرهاى مخرب آن بر عمليات و و رفتار

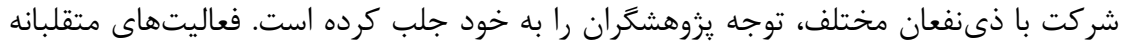

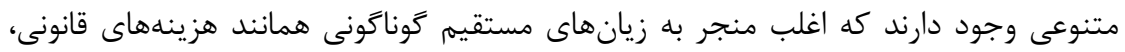
ادعاهاى مشتريان و جريمههاى قانونى مىشوند. با وجود اين، در مقابل زيانهاى مانى مستقيم،

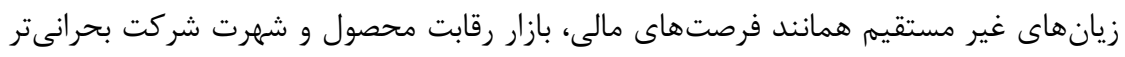

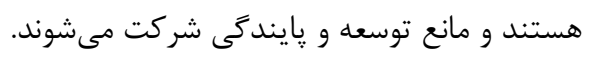

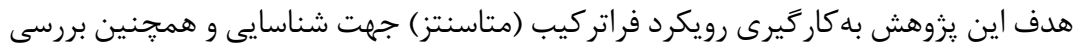
عوامل مؤثر بر كزارشخَى مالى متقلبانه و نادرست مى باشد. بدين منظور يزوهشكران تحقيق 
حاضر تعداد الاس يزوهش را به منظور شناسايى شاخصهاى مرتبط با كزارشكرى متقلبانه و

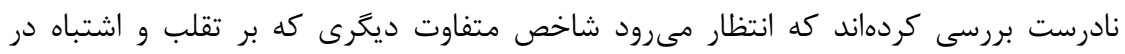

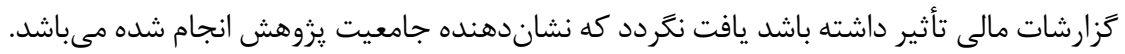

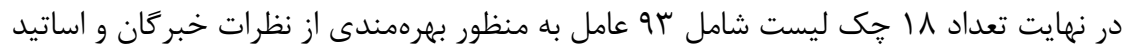

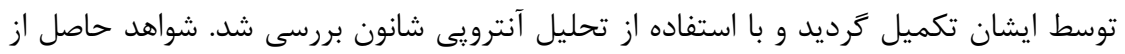

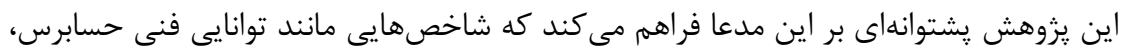

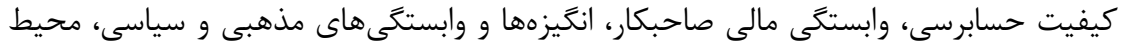

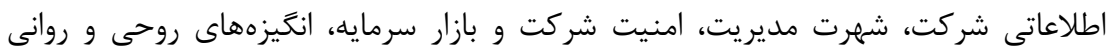

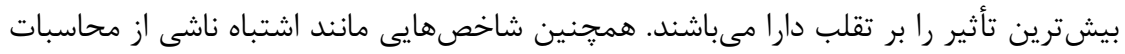

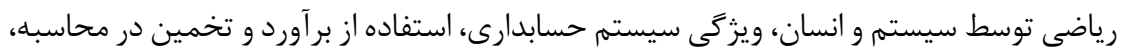

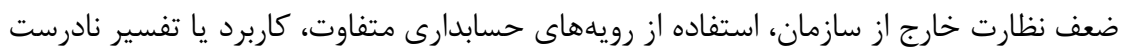

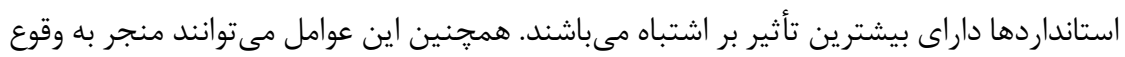

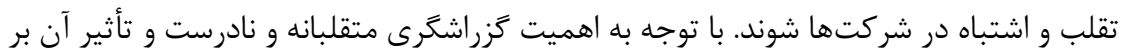

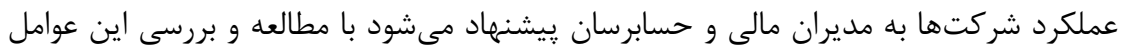

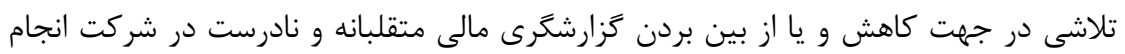

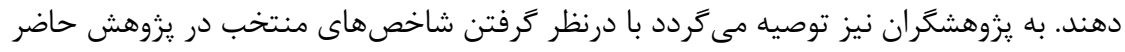

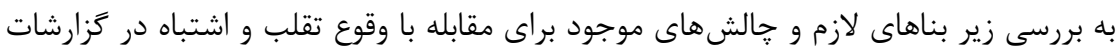
مالى بيردازند. در انتها بايد اذعان كرد كه همانند ساير يزوهشها، مطالعه حاضر نيز با محدوديتهايى مواجه

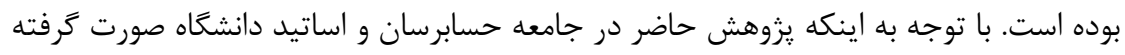

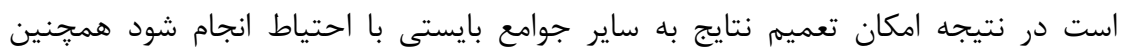

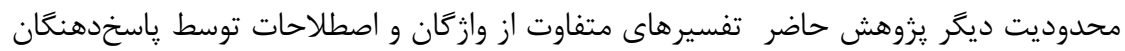
در رِاسخ به سوالات مىباشد.

\section{فهرست منابع}

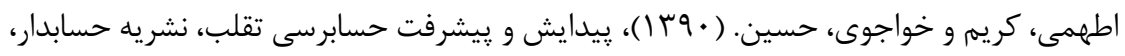

$$
\text { سال צrا،شماره Y)، صص }
$$

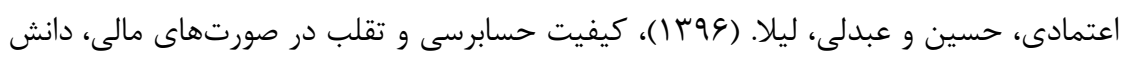

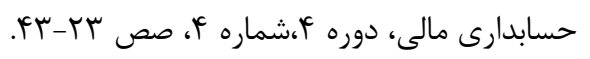


اعتمادى، حسين؛ سارى، محمدعلى؛ جوانى قلندرى، موسى. (Y (I))، احتمال تجديد ارائه

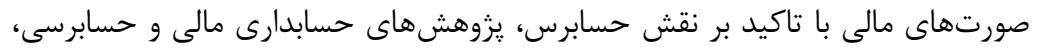

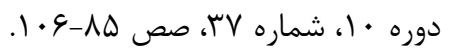

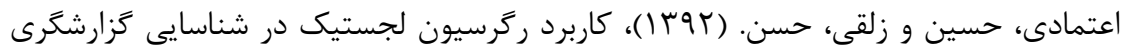

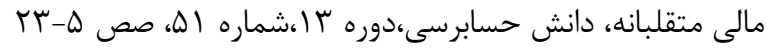

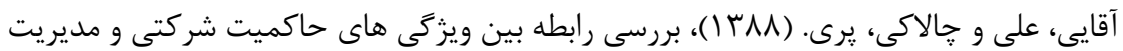

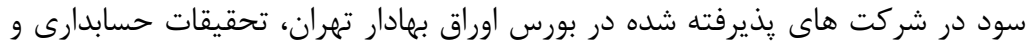

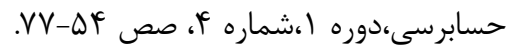

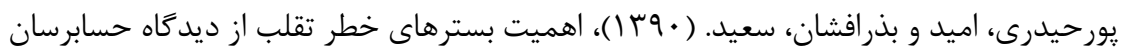

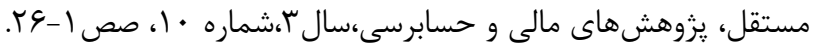

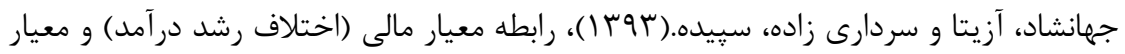

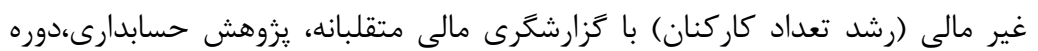

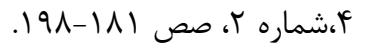

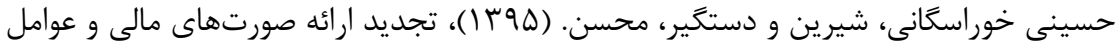

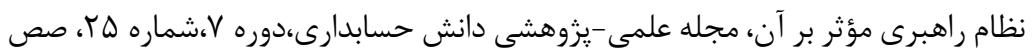

$.141-1 \cdot 1$

حجازى،رضوان و مختارى نزاد، حميدرضا. (ع (1))، بررسى تأثير ويزگى هاى هيأت مديره بر

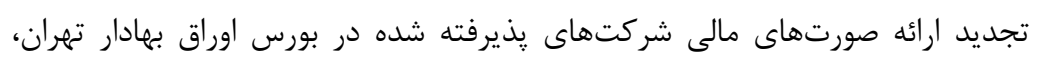

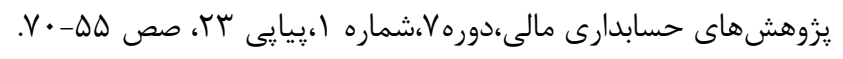

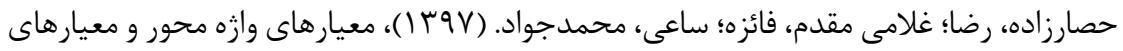

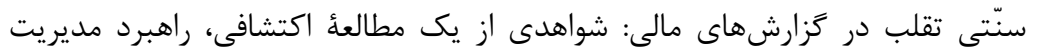

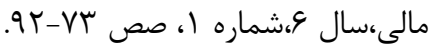

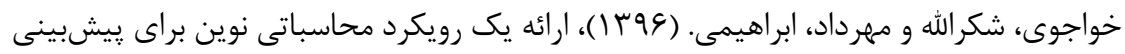

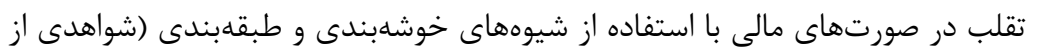

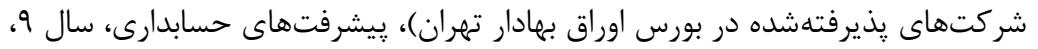

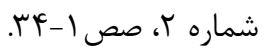

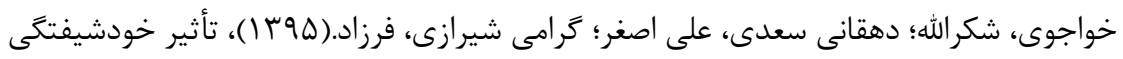

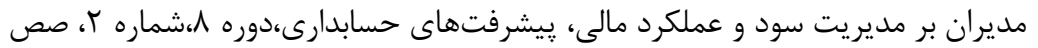




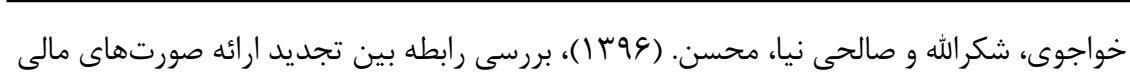

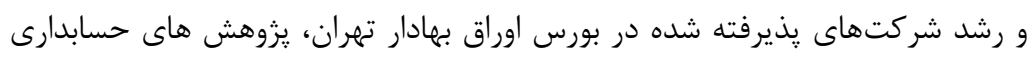

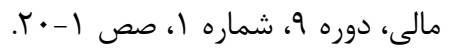

$$
\begin{aligned}
& \text { خواجوى، شكرالله و قديريان آرانى، محمد حسين. (Y (1))، بررسى تأثير كيفيت سود بر تجديد }
\end{aligned}
$$

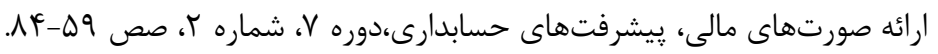

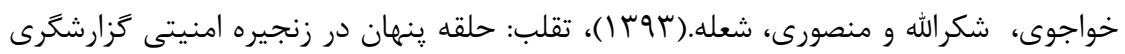

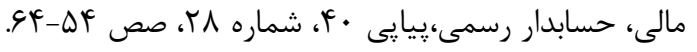

$$
\begin{aligned}
& \text { ديانتى ديلمى،زهرا.(1) (1)). روش تحقيق كيفى و كمى در حسابدارى. تهران: عدالت نوين. }
\end{aligned}
$$

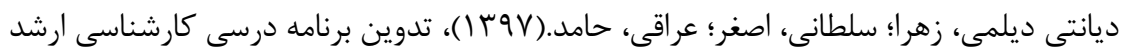

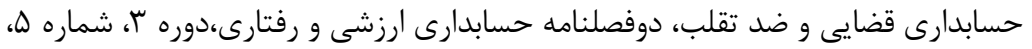

$$
\begin{aligned}
& \text { صص أt-1. (1) } \\
& \text { رستمى، محمد رضا و جعفرى درگيرى، اعظم. (Y (I))، بررسى قانون بنفورد در بورس اوراق }
\end{aligned}
$$

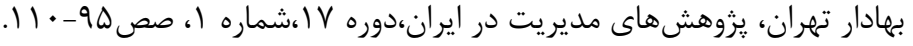

$$
\begin{aligned}
& \text { رهنماى روديشتى، فريدون.( (1 (1)، داده كاوى و كشف تقلبهاى مالى، فصلنامه علمى يزوهش }
\end{aligned}
$$

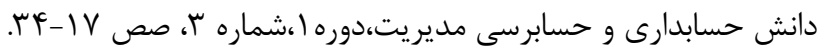

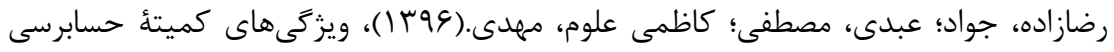

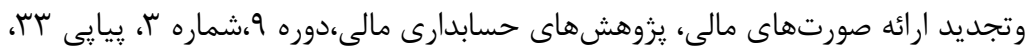

$$
\begin{aligned}
& \text { صص 19-19. }
\end{aligned}
$$

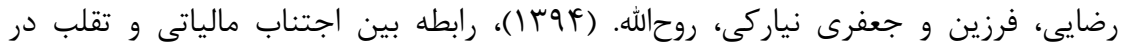

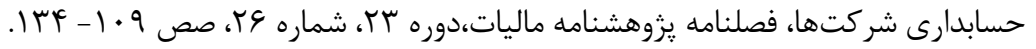

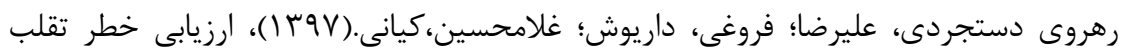

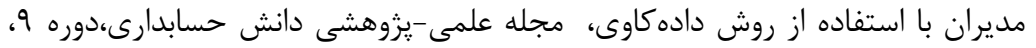

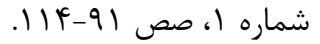

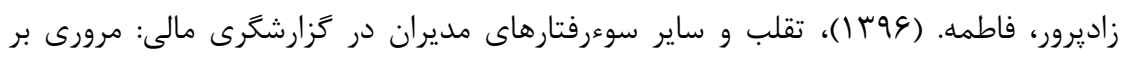

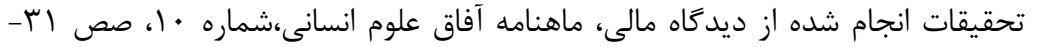

$$
\begin{aligned}
& \text { Tr } \\
& \text { زارع بهنميرى، محمدجواد و ملكيان كله بستى، اسفنديار. (هوب ا)، رتبلهبندى عوامل مؤثر بر } \\
& \text { احتمال تقلب مالى با توجه به گزارش حسابرسى صورتهاى مالى، يزوهشئهاى تجربى }
\end{aligned}
$$

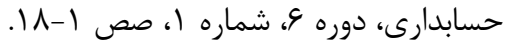




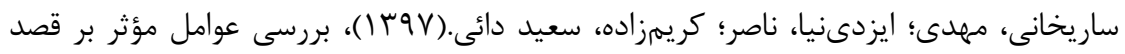

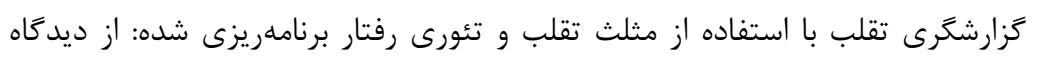

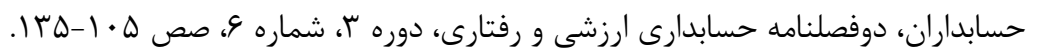

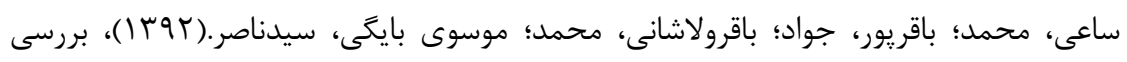

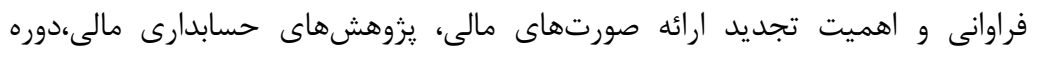

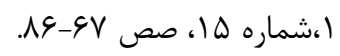

سجادى، سيد حسين و كاظمى، توحيد.( (9 1)، الكَوى جامع كزارشكَرى مالى متقلبانه در ايران

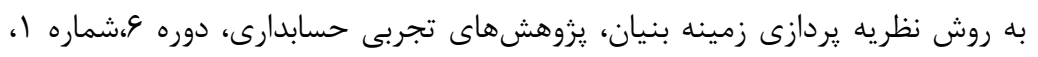

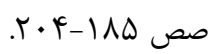

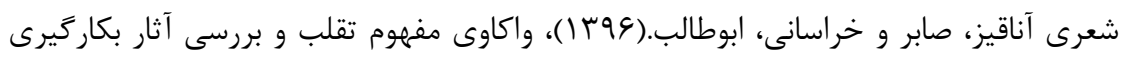

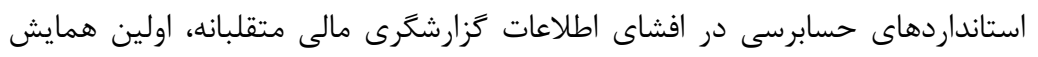

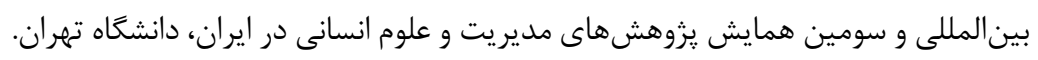

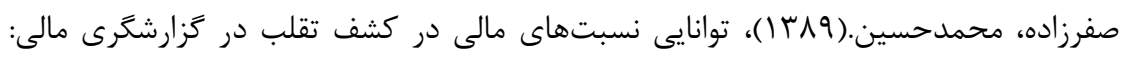

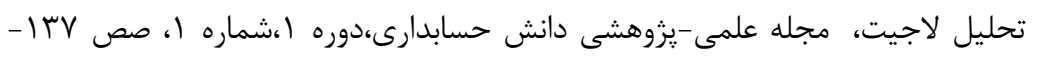

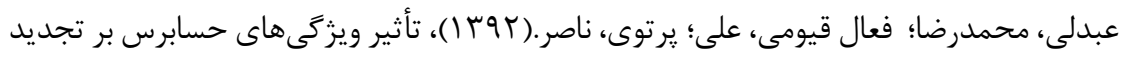

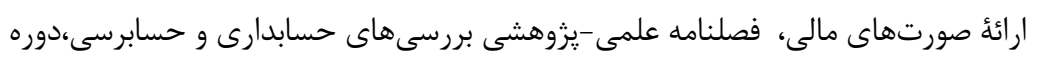

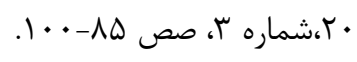

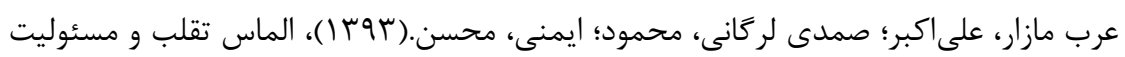

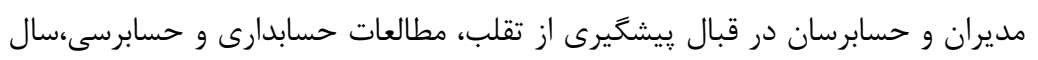

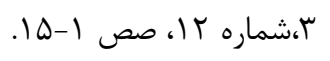

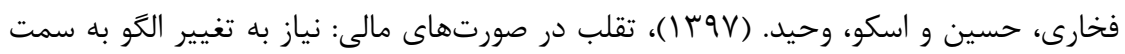

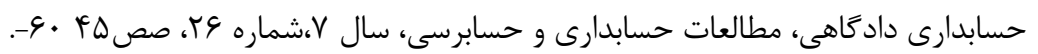

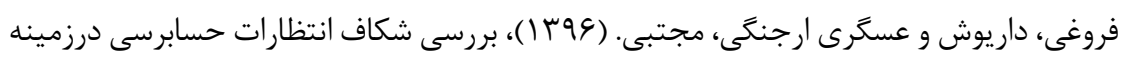

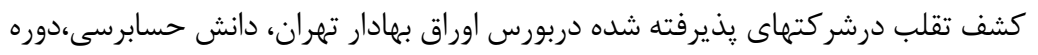

$$
\text { VIV }
$$

كاردان، بهزاد؛ لارى دشتبياض، محمود؛ منصورى، مرتضى. (ه9 (1)، بررسى تأثير تجديد ارائه

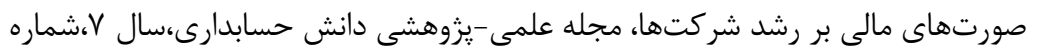




$$
\begin{aligned}
& \text { كمالى كرمانى، نرجس؛ بصيرزاده، محمد حسين؛ زرد كوهى، محسن؛ دل آرام ،محمد؛ طالبى نجف }
\end{aligned}
$$

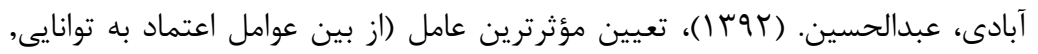

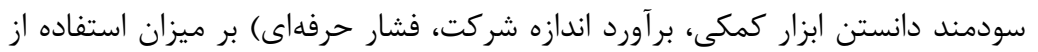

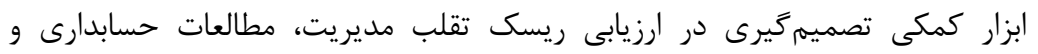

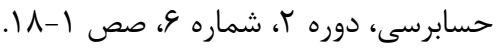

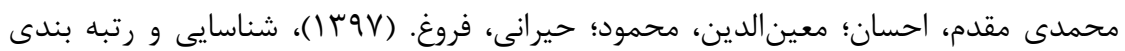

$$
\begin{aligned}
& \text { عوامل مؤثر بر احتمال بروز تقلب يا اعمال مجرمانه توسط حسابداران با استفاده از نظريه }
\end{aligned}
$$

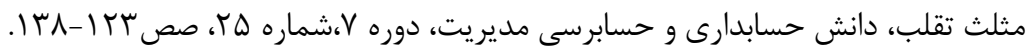

$$
\begin{aligned}
& \text { مرادى، جواد و قديريان آرانى، محمد حسين. (وه (I)، بيشاعتمادى مديريت و تجديد ارائه } \\
& \text { صورتهاى مالى: شواهدى از بورس اوراق بهادار تهران، يِيشرفتهاى حسابدارى، دوره }
\end{aligned}
$$

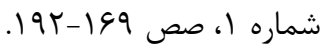

$$
\begin{aligned}
& \text { مرادى، جواد؛ رستمى، راحله؛ زارع، رضا. (سوسا)، شناسايى عوامل خطر مؤثر بر احتمال وقوع }
\end{aligned}
$$

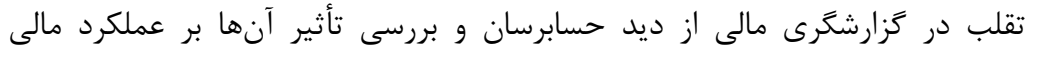

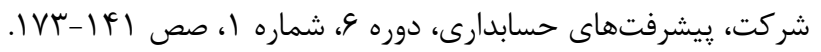

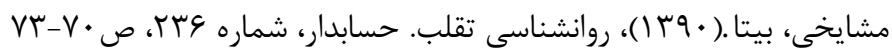

$$
\begin{aligned}
& \text { موسوى، سيد رضا؛ جبارى، حسين؛ طالب بيدختى، عباس. (YF (1))، حاكميت شركتى و تجديد }
\end{aligned}
$$

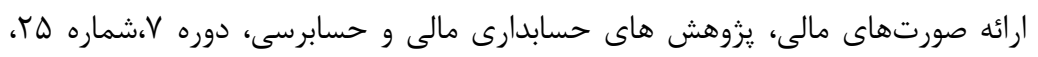

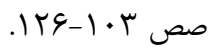

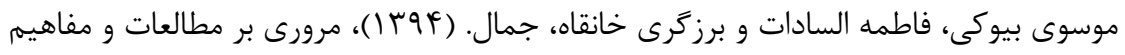

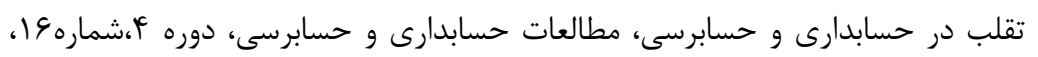

$$
\begin{aligned}
& \text { صص } \\
& \text { مهدوى، غلامحسين و قهرمانى، عليرضا. (צوبا)، ارائه الكويى براى كشف تقلب به وسيله }
\end{aligned}
$$

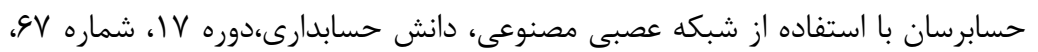

$$
\begin{aligned}
& \text { صص }
\end{aligned}
$$

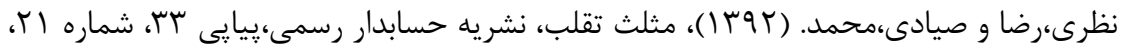

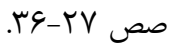

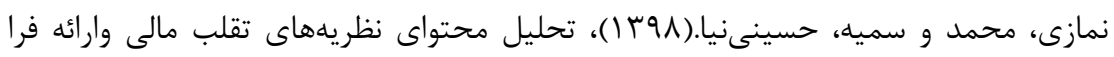

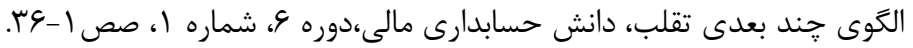

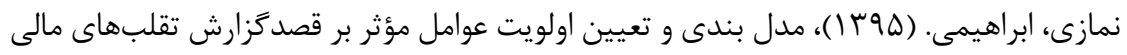

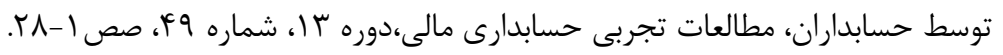




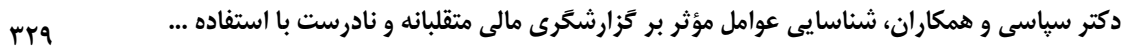

$$
\begin{aligned}
& \text { نيكبخت، محمدرضا و شيخ، محمدجواد. (r/Mr)، بررسى اهميت شاخصهاى تقلب بالقوه }
\end{aligned}
$$

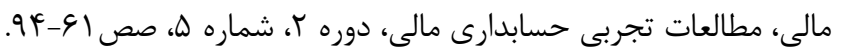

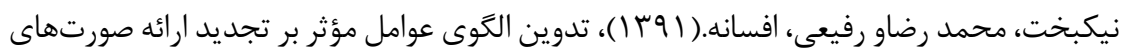

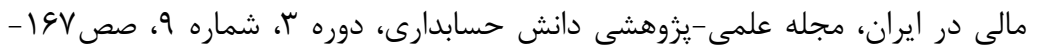

$$
\begin{aligned}
& .194 \\
& \text { وادىزاده، كاظم و عيسايى خوش، احمد. (• وسا)، قله كوه يخ، نشريه حسابدار، سال ه } \\
& \text { 9. } \\
& \text { وديعى، محمد حسين؛ باقريور ولاشانى، محمدعلى؛ سيفى قبادى، حسين. (هو (1)، بررسى تاثير }
\end{aligned}
$$

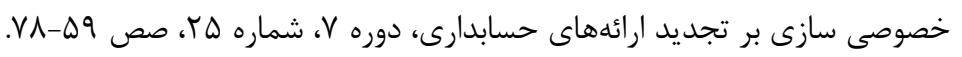

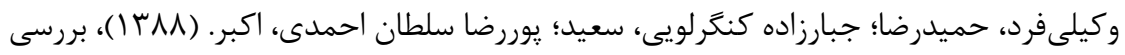

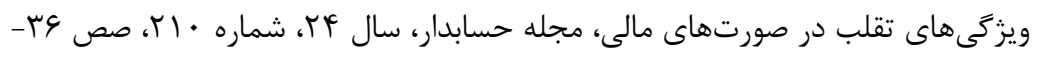

$$
\begin{aligned}
& \text {. I) } \\
& \text { هاشمى، سيدعباس و حريرى، اميرسينا. (9 (1)، ارزيابى توانايى قانون بنفورد در شناسايى و }
\end{aligned}
$$

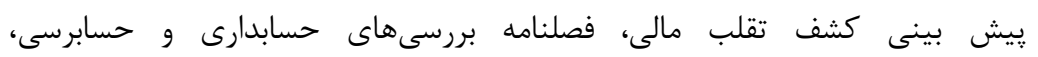

$$
\begin{aligned}
& \text { دوره זr، شماره r. }
\end{aligned}
$$

Acito, A. A., J. J. Burks, and W. B. Johnson. 2019. The Materiality of Accounting Errors: Evidence from SEC Comment Letters. Contemporary Accounting Research 36(2): 839-868.

Agrawal, A., and S. Chadha. 2005. Corporate governance and accounting scandals. The Journal of Law and Economics 48(2): 371-406.

Albrecht, W., C. C. Albrecht, and C. O. Albrecht. 2004. Fraud and corporate executives: Agency, stewardship and broken trust. Journal of Forensic Accounting 5: 109-130.

Albrecht, C., D. Holland, R. Malagueno, S. Dolan, and S. Tzafrir. 2015. The role of power in financial statement fraud schemes. Journal of Business Ethics 131(4): 803-813.

Alden, M. E., D. M. Bryan, B. J. Lessley, and A. Tripathy. 2012. Detection of financial statement fraud using evolutionary algorithms. Journal of Emerging Technologies in Accounting 9(1): 71-94.

Ali, A. M., J. D. Gloeck, and T. H. Lee. 2008. A study of auditors' responsibility for fraud detection in Malaysia. Southern African Journal of Accountability and Auditing Research 8(1): 27-34.

Allee, K. D., B. Baik, and Y. Roh. 2019. Detecting Financial Misreporting with Real Production Activity. Available at: https://papers.ssrn.com/sol3/papers.cfm?abstract_id=2856472

Amara, I., A. B. Amar, and A. Jarboui. 2013. Detection of fraud in financial statements: French companies as a case study. International Journal of 
Academic Research in Accounting, Finance and Management Sciences 3(3): 40-51.

Amiram, D., Z. Bozanic, J. D. Cox, Q. Dupont, J. M. Karpoff, and R. Sloan. 2018. Financial reporting fraud and other forms of misconduct: a multidisciplinary review of the literature. Review of Accounting Studies 23(2): 732-783.

Amiram, D., Z. Bozanic, and E. Rouen. 2015. Financial statement errors: Evidence from the distributional properties of financial statement numbers. Review of Accounting Studies 20(4): 1540-1593.

Anderson, K. L., and T. L. Yohn. 2002. The effect of 10K restatements on firm value, information asymmetries, and investors' reliance on earnings. Available at: https://papers.ssrn.com/sol3/papers.cfm?abstract_id=332380

Bani ahmad, A. 2019. The moderating role of internal control on the relationship between accounting information system and detection of fraud: the case of Jordanian banks. International journal of academic research in economics \& management science 8(1): 37-48.

Beasley, M. S. 1996. An empirical analysis of the relation between the board of director composition and financial statement fraud. Accounting review 71(4): 443-465.

Beasley, M. S., J. V. Carcello, D. R. Hermanson, and P. D. Lapides. 2000. Fraudulent financial reporting: Consideration of industry traits and corporate governance mechanisms. Accounting Horizons 14(4): 441-454.

Berger, P. G., and Lee, H. 2019. Do Corporate Whistleblower Laws Deter Accounting Fraud? Available at: https://papers.ssrn.com/sol3/papers.cfm?abstract_id $=3059231$

Brazel, J. F., K. L. Jones, and M. F. Zimbelman. 2009. Üsing nonfinancial measures to assess fraud risk. Journal of Accounting Research 47(5): 1135-1166.

Burns, N., and S. Kedia. 2006. The impact of performance-based compensation on misreporting. Journal of financial economics 79(1): 35-67.

Bushman, R. M., J. D. Piotroski, and A. J. Smith. 2004. What determines corporate transparency? Journal of accounting research 42(2): 207-252.

Callen, J. L., J. Livnat, and D. Segal. 2006. Accounting restatements: Are they always bad news for investors? The Journal of Investing 15(3): 57-68.

Catalano, A. 2013. Patterns of graduate students' information seeking behavior: a meta-synthesis of the literature. Journal of documentation 69 (2): 243-274.

Chan, K. H., K. Z. Lin, and F. Zhang. 2007. On the association between changes in corporate ownership and changes in auditor quality in a transitional economy. Journal of International Accounting Research 6(1): 19-36.

Chen, F. H., D. J. Chi, and J. Y. Zhu. 2014. Application of Random Forest, Rough Set Theory, Decision Tree and Neural Network to Detect Financial Statement Fraud-Taking Corporate Governance into Consideration. International Conference on Intelligent Computing :221-234.

Chen, G., M. Firth, D. N. Gao, and O. M. Rui. 2006. Ownership structure, corporate governance, and fraud: Evidence from China. Journal of Corporate Finance 12(3): 424-448. 
دكتر سياسى و همكاران، شناسايى عوامل مؤثر بر تَزارشكَرى مالى متقلبانه و نادرست با استفاده ... اسب

Choudhary, P., K. Merkley, and K. Schipper. 2016. Qualitative characteristics of financial reporting errors deemed immaterial by managers. Working Paper University of Arizona.

Cianci, A. M., S. M. Clor-Proell, and S. E. Kaplan. 2018. How do investors respond to restatements? Repairing trust through managerial reputation and the announcement of corrective actions. Journal of Business Ethics 158(12): 297312.

Davis, M. V. 2019. Strategies to Prevent and Detect Occupational Fraud in Small Retail Businesses. Working paper, Walden university scholar works.

DeAngelo, L. E. 1981. Auditor size and audit quality. Journal of accounting and economics 3(3): 183-199.

Dechow, P. M., R. G. Sloan, and A. P. Sweeney. 1996. Causes and consequences of earnings manipulation: An analysis of firms' subject to enforcement actions by the SEC. Contemporary accounting research 13(1): 1-36.

DeFond, M. L., and J. Jiambalvo.1991. Incidence and circumstances of accounting errors. Accounting review 66(3): 643-655.

Efendi, J., A. Srivastava, and E. P. Swanson. 2007. Why do corporate managers misstate financial statements? The role of option compensation and other factors. Journal of financial economics 85(3): 667-708.

Fang, V. W., A. H. Huang, and W. Wang. 2017. Imperfect accounting and reporting bias. Journal of Accounting Research 55(4): 919-962.

Fanning, K., K. O. Cogger, and R. Srivastava. 1995. Detection of management fraud: A neural network approach. Intelligent Systems in Accounting, Finance and Management 4(2): 113-126.

Feroz, E. H., T. M. Kwon, V. S. Pastena, and K. Park. 2000. The efficacy of red flags in predicting the SEC's targets: an artificial neural networks approach. Intelligent Systems in Accounting, Finance \& Management 9(3): 145-157.

Fischer, P. E., and R. E. Verrecchia. 2000. Reporting bias. The Accounting Review 75(2): 229-245.

Gerety, M., and K. Lehn. 1997. The causes and consequences of accounting fraud. Managerial and Decision Economics 18(7-8): 587-599.

Gertsen, F. H., C. B. van Riel, and G. Berens. 2006. Avoiding reputation damage in financial restatements. Long Range Planning 39(4): 429-456.

Grove, H., and E. Basilico. 2008. Fraudulent financial reporting detection: Key ratios plus corporate governance factors. International Studies of Management \& Organization 38(3): 10-42.

Hee, K. W. 2008. Earnings persistence of restating firms: Should all earnings restatements be treated equally? (Doctoral dissertation, University of Colorado at Boulder, Available at: https://search.proquest.com/openview/99dfafd9e72e8d985e062cef9b013311/ 1?pq-origsite $=$ gscholar $\& \mathrm{cbl}=18750 \&$ diss $=y$

Hennes, K. M., A. J. Leone, and B. P. Miller. 2012. Auditor dismissals after accounting Restatements. Available at: https://pdfs.semanticscholar.org/ed30/7cdcbeb76f77d20b9e67645681c74d8c ecf4.pdf 
Horton, J., D. Krishnakumar, and A. Wood. 2018. Detecting Academic Fraud in Accounting Research: The Case of Professor James Hunton. Available at: https://papers.ssrn.com/sol3/papers.cfm?abstract_id=3164961

Hribar, P., and N. T. Jenkins. 2004. The effect of accounting restatements on earnings revisions and the estimated cost of capital. Review of accounting studies 9(23): 337-356.

Huang, S. Y., R. H. Tsaih, and F. Yu. 2014. Topological pattern discovery and feature extraction for fraudulent financial reporting. Expert systems with applications 41(9): 4360-4372.

Hylas, R. E., and R. H. Ashton. 1982. Audit detection of financial statement errors. Accounting Review 57(4): 751-765.

Ionescu, L. 2017. Errors and fraud in accounting. The role of the external audit in fighting corruption. Annals of SpiruHaret University. Economic Series 17(4): 29-36.

Jan, C. L. 2018. An effective financial statements fraud detection model for the sustainable development of financial markets: Evidence from Taiwan. Sustainability 10(2): 513.

Johnson, W. C., W. Xie, and S. Yi. 2014. Corporate fraud and the value of reputations in the product market. Journal of Corporate Finance 25: 16-39.

Kaminski, K. A., T. Sterling Wetzel, and L. Guan. 2004. Can financial ratios detect fraudulent financial reporting? Managerial Auditing Journal 19(1): 15-28.

Kinney Jr, W. R., and L. S. McDaniel. 1989. Characteristics of firms correcting previously reported quarterly earnings. Journal of accounting and economics 11(1): 71-93.

Kinney Jr, W. R., Z. V. Palmrose, and S. Scholz. 2004. Auditor independence, nonaudit services, and restatements: Was the US government, right? Journal of Accounting Research 42(3): 561-588.

Kirkos, E., C. Spathis, and Y. Manolopoulos. 2007. Data mining techniques for the detection of fraudulent financial statements. Expert systems with applications 32(4): 995-1003.

Laffin, M., and T. Gomes. 2013. The Prevention of Error and Fraud in Accounting. International Journal of Advances in Management and Economics 2(5): 125-131.

Lisowsky, P., L. Robinson, and A. Schmidt. 2013. Do publicly disclosed tax reserves tell us about privately disclosed tax shelter activity? Journal of Accounting Research 51(3): 583-629.

Menk, K. B. 2011. The impact of materiality, personality traits, and ethical position on whistle-blowing intentions. Theses and Dissertations, Virginia Commonwealth University.

Okoye, E., and E. N. Ndah. 2019. Forensic accounting and fraud prevention in manufacturing companies in Nigeria. International Journal of Innovative Finance and Economics Research 7(1): 107-116.

Owusu-Ansah, S., G. D. Moyes, P. Babangida Oyelere, and D. Hay. 2002. An empirical analysis of the likelihood of detecting fraud in New Zealand. Managerial Auditing Journal 17(4): 192-204. 


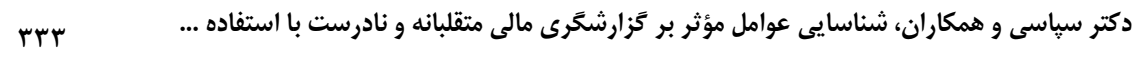

Pamungkas, I. D., I. Ghozali, and T. Achmad. 2018. A pilot study of corporate governance and accounting fraud: The fraud diamond model. Journal of Business and Retail Management Research 12(2): 253-261.

Perols, J. L. 2008. Detecting financial statement fraud: Three essays on fraud predictors, multi-classifier combination and fraud detection using data mining. Working paper, University of south Florida.

Persons, O. S. 1995. Using financial statement data to identify factors associated with fraudulent financial reporting. Journal of Applied Business Research (JABR) 11(3): 38-46.

Povel, P., R. Singh, and A. Winton. 2007. Booms, busts, and fraud. The Review of Financial Studies 20(4): 1219-1254.

Ramos, M. 2003. Auditors' responsibility for fraud detection. Journal of Accountancy 195(1): 28-36.

Ramos Montesdeoca, M., A. J. Sánchez Medina, and F. Blázquez Santana. 2019. Research Topics in Accounting Fraud in the 21st Century: A State of the Art. Sustainability, 11(6): 1-31.

Rezaee, Z. 2005. Causes, consequences, and deterrence of financial statement fraud. Critical Perspectives on Accounting 16(3): 277-298.

Romanus, R. N., J. J. Maher, and D. M. Fleming. 2008. Auditor industry specialization, auditor changes, and accounting restatements. Accounting Horizons 22(4): 389-413.

Mohd nor, J., N. Ahmad, and N. Mohd Saleh. 2010. Fraudulent financial reporting and company characteristics: tax audit evidence. Journal of Financial Reporting and Accounting, 8(2): 128-142.

Nahar Abdullah, S., N. Zalina Mohamad Yusof, and M. Naimi Mohamad nor. 2010. Financial restatements and corporate governance among Malaysian listed companies. Managerial Auditing Journal 25(6): 526-552.

Schrand, C. M., and S. L. Zechman. 2012. Executive overconfidence and the slippery slope to financial misreporting. Journal of Accounting and economics 53(1-2): 311-329.

Sharma, A., and P. K. Panigrahi. 2013. A review of financial accounting fraud detection based on data mining techniques. International Journal of Computer Applications 39 (1): 37-47.

Shelton, S. W., L. A. Owens-Jackson, and D. R. Robinson. 2011. IFRS and US GAAP: Assessing the impact of reporting incentives on firm restatements in foreign and US markets. Advances in Accounting 27(1): 187-192.

Simbolon, R., N. Ahmad, and S. Elviani. 2019. Are the Model of Fraud Triangle Elements Sufficient Enough to Prevent Fraud? Evidence in North Sumatra Province. In 1st International Conference on Social Sciences and Interdisciplinary Studies. Atlantis Press.

Spathis, C. T. 2002. Detecting false financial statements using published data: some evidence from Greece. Managerial Auditing Journal 17(4): 179-191.

Stanley, J. D., and F. T. DeZoort. 2007. Audit firm tenure and financial restatements: An analysis of industry specialization and fee effects. Journal of Accounting and Public Policy 26(2): 131-159. 
Summers, S. L., and J. T. Sweeney. 1998. Fraudulently misstated financial statements and insider trading: An empirical analysis. Accounting Review 73(1): 131146.

Uzun, H., S. H. Szewczyk, and R. Varma. 2004. Board composition and corporate fraud. Financial Analysts Journal 60(3): 33-43.

Wang, Y., J. K. Ashton, and A. Jaafar. 2019. Does mutual fund investment influence accounting fraud? Emerging Markets Review 38: 142-158.

Wang, Z., M. H. Chen, C. L. Chin, and Q. Zheng. 2017. Managerial ability, political connections, and fraudulent financial reporting in China. Journal of Accounting and Public Policy 36(2): 141-162.

Wang, X., and M. Wu. 2011. The quality of financial reporting in China: An examination from an accounting restatement perspective. China Journal of Accounting Research 4(4): 167-196.

Whiting, D. G., J. V. Hansen, J. B. McDonald, C. Albrecht, and W. S. Albrecht. 2012. Machine learning methods for detecting patterns of management fraud. Computational Intelligence 28(4): 505-527.

Wu, M. 2002. Earnings restatements: A capital market perspective. Available at: https: //papers.ssrn.com/sol3/papers.cfm?abstract_id $=1844265$

Yuan, Q., and Y. Zhang. 2016. The real effects of corporate fraud: Evidence from class action lawsuits. Accounting \& Finance 56(3): 879-911.

Zhou, W., and G. Kapoor. 2011. Detecting evolutionary financial statement fraud. Decision Support Systems 50(3): 570-575.

Zainudin, E. F., and H. A. Hashim. 2016. Detecting fraudulent financial reporting using financial ratio. Journal of Financial Reporting and Accounting 14(2): 266-278. 